\title{
Greater investments in children through women's empowerment: A key to demographic change in Pakistan?
}

\author{
Valerie L. Durrant \\ Zeba Sathar \\ Population Council
}

Follow this and additional works at: https://knowledgecommons.popcouncil.org/departments_sbsr-pgy

Part of the Demography, Population, and Ecology Commons, Family, Life Course, and Society Commons, Gender Equity in Education Commons, International Public Health Commons, and the Maternal and Child Health Commons How does access to this work benefit you? Let us know!

\section{Recommended Citation}

Durrant, Valerie L. and Zeba Sathar. 2000. "Greater investments in children through women's empowerment: A key to demographic change in Pakistan?" Policy Research Division Working Paper no. 137. New York: Population Council. 


\title{
Greater Investments in Children Through Women's Empowerment: A Key to Demographic Change in Pakistan?
}

\author{
Valerie L. Durrant
}

Zeba A. Sathar 


\title{
Greater Investments in Children Through Women's Empowerment: A Key to Demographic Change in Pakistan?
}

\author{
Valerie L. Durrant \\ Zeba A. Sathar
}

Valerie L. Durrant is study director at the National Research Council, Committee on Population. Zeba A. Sathar is deputy representative at the Population Council, Pakistan. Correspondence should be addressed to Valerie L. Durrant, National Research Council, Committee on Population, 2101 Constitution Avenue NW, Washington, DC 20418; e-mail: vdurrant@nas.edu.

The authors are thankful for comments from Cynthia Lloyd. An earlier version of this paper was presented at the Annual Meeting of the Population Association of America, Los Angeles, CA, 23-25 March 2000. 


\begin{abstract}
Women's status has received considerable attention as a significant factor in demographic behavior and outcomes in South Asia; however, little research has addressed the links between women's status and their investments in children. In this paper, we empirically investigate how women's status on multiple levels is associated with demographic outcomes. Using data from the Pakistan Status of Women and Fertility Survey in rural Punjab, we confirm that empowered women, or those with higher status, are better able to make positive investments in their children, thus increasing their children's chances of survival during infancy and increasing their likelihood of ever attending school. It is in examining these two outcomes in combination that the multiple dimensions of women's status at the micro and macro levels become most apparent. Overall, the data support our hypotheses that improvements in women's status at the individual level, particularly in terms of improvement of women's position within the household, will enhance child survival, whereas improvements in women's status at the more general community level will improve the schooling chances of children, especially girls. Specifically, higher levels of women's status at the individual level, particularly in terms of access to financial resources and the absence of purdah restrictions and physical abuse by husbands, are associated with a lower likelihood of infant mortality. On the other hand, higher mean levels of women's mobility and lower levels of fear of disagreeing with husbands in a community are associated with a higher likelihood that children, especially girls, will ever attend school.
\end{abstract}

This material may not be reproduced without written permission from the authors. 
Women's status has received considerable attention as a significant factor affecting demographic behavior and outcomes in the South Asian context. The well-developed body of theoretical work and the substantial empirical research on the relationship between women's status and demographic behavior, largely using women's education as a proxy for status, have been supplemented with the increasing availability of data that directly address different aspects of women's status. Research supports the view that low status of women-characterized by limited mobility; weak decisionmaking autonomy; and restricted access to resources, especially those that equip women to earn an income-significantly influences women's reproductive intentions and behaviors throughout the region (for data on Bangladesh see, for example, Balk 1994 and Schuler and Hashemi 1994; for India see Dyson and Moore 1983; Malhotra, Vanneman, and Kishor 1995; Jejeebhoy 1996; and Visaria 1996; for Nepal see Morgan and Niraula 1995; and for Pakistan see Sathar 1993; Smith et al. 1995; and Sathar and Kazi 1996). However, most of the empirical research in this area has concentrated on the influences of women's status on fertility. Much less research on women's status has been focused on using direct measures to assess the links between women's status and their behaviors once their children are born. In other words, the influence of women's status on demographic transitions has concentrated on quantity of children and has neglected, or taken for granted, investments in the quality of children. While family decisions regarding the quantity and quality of children are often closely linked, a closer look at the latter offers additional insight into family-building strategies.

Pakistan is widely recognized as a highly patriarchal country that attaches little social value to women and girls and that exhibits high levels of gender inequality in social and economic arenas as well as within households. While this description encompasses most countries in South Asia, it is coupled in Pakistan with high fertility levels that have been stubbornly resistant to change until only recently (Sathar and Casterline 1998); low levels of schooling, particularly among girls and women in rural areas (Government of Pakistan 1997; World Bank 1998); and alarmingly high levels of infant and maternal mortality (World Bank 1998). For example, the infant mortality rate in Pakistan is 95, compared to 83 in Nepal, 75 in Bangladesh, and 71 in India (World Bank 1998); this is notable particularly given Pakistan's better global economic position relative to other countries in the region. Thus it is surprising that little research has ad- 
dressed the relationships between women's status in Pakistan and the survival and situations of their children.

This paper attempts to address the gap in empirical studies that investigate the influences of women's status on investments in children, focusing specifically on infant survival and children's schooling. Given the low investments in children (as depicted by the unusually high levels of infant mortality and low levels of school attendance) and the low status of women in Pakistan, identifying the factors that improve the survival and situation of women and children is critical, particularly those factors that are related to women's position in society. We argue that Pakistani women who are more empowered are likely to be more motivated and able to make greater investments in their children, just as they are likely to want smaller families and to use contraception as demonstrated in the literature cited above. We further argue, not unlike other researchers, that because women's status has multiple facets, operates at multiple levels, and varies by context, not all aspects of women's status will share an equal or identical role in processes that enable women to invest in their children. Different aspects of women's status may be important for different types of investments, and identifying these relationships offers valuable information on women's empowerment as well as on each investment outcome.

Our challenge in this paper is to determine which aspects of women's statusand at what levels - are important in explaining positive investments in children in the context of rural Pakistan. In setting up specific hypotheses, we build on the existing empirical literature. Capitalizing on the rich data on women's status from a 1993-94 survey carried out in Punjab, we investigate the pathways through which different aspects of women's status affect infant survival and children's schooling in the rural Punjabi

setting. While the situation of rural women in Punjab may not be generalizable across other areas of Pakistan or South Asia, the context is useful for gaining insight into women's status in patriarchal settings and women's ability to invest in their children.

\section{THEORETICAL FRAMEWORK:}

\section{MULTIPLE Dimensions OF WOMEN's STATUS}

The theoretical framework for this study is based on extensive theoretical and empirical research that outlines the pathways through which women's autonomy influ- 
ences demographic behavior at micro and macro levels (Mason 1984, 1987, 1993; Smith 1989; Smith et al. 1995). We briefly summarize the central aspects of this framework that are important to our model. For a thorough discussion of the relationship between women's status and demographic outcomes, see Mason 1984 and 1993.

First, theoretical and empirical literature supports the view that women's status is multidimensional in nature. Because a woman's status comprises multiple characteristics of the woman and her relationships with others, it is impossible to capture the influence of and understand women's status through a single measure. Dimensions including, but not limited to, freedom of movement, access to financial and nonfinancial resources, decisionmaking autonomy, gender attitudes, freedom from fear and coercion, and equality in her relationship with her partner are arguably important but distinct aspects of a woman's position in relation to men, other family members, and other women (Federici, Mason, and Sogner 1993; Mason 1993). Empirical studies of women's status in South Asia support this multidimensionality and demonstrate that various aspects of women's status have different determinants and little correlation with each other (Balk 1994, 1997; Jejeebhoy 1996; Kazi and Sathar 1996; Mason 1998). Moreover, concurrently examining multiple dimensions of women's status informs us about the pathways through which women's status operates on demographic outcomes (Mason 1993).

Second, the cultural and historical context is important (Federici, Mason, and Sogner 1993). At the core of the framework is the notion that gender inequality at the individual level and within the household is related to but distinct from "gender systems of stratification" at the macro level (Mason 1984) and that comprehensive and accurate models of outcomes believed to be affected by gender inequality must incorporate women's status at multiple (albeit theoretically appropriate) levels. In other words, behavior at the individual level occurs within gender norms at the household and community levels, and the multiple layers of women's status, and how they overlap, have important implications for the actions of women. For example, individual mobility in a community where few women can leave the house unescorted has different implications than an individual woman's movement in a community where many women can move freely.

Finally, the relationship between various aspects of women's status and demographic outcomes will differ with the demographic outcome under consideration. Ma- 
son (1993) supports this on a general level by using findings from several studies to show that women's status (often measured by women's education and/or employment) appears to have a direct or conditioning influence on the mortality transition but an indirect and more speculative effect on fertility change.

Because the character of the investments in children through health and schooling differ, we expect the pathways through which women's status is influential to differ as well. These differences allow us to better explore the mechanisms through which women's status influences investments in children-thus gaining insight into infant mortality and children's schooling as well as women's status.

\section{EVIDENCE OF THE EFFECTS OF WOMEN'S STATUS ON INVESTMENT IN CHILDREN}

Although few researchers have addressed the relationship between women's status and investments in children specifically, the idea that women's empowerment has positive consequences on children in terms of improving their health and survival and/ or schooling is not new. Many studies—dating back at least to Caldwell's (1979) seminal study on education and mortality—use women's education and employment as proxies for women's status, particularly as related to infant and child mortality. Because research on women's education and, to a lesser extent, employment provides the basis for many of the current studies that make use of more precise measures of women's status, we begin our literature review with a discussion of these studies and then turn to those that use more direct measures of women's status in order to develop our hypotheses.

\section{Women's Education}

A large number of studies look at the effect of women's education on infant mortality or children's schooling in Pakistan and other countries and show consistent results: higher levels of women's education are associated with a higher probability of infant and child survival and with higher levels of school attendance among children (see Ware 1984; Hobcraft 1993; Basu 1994; Caldwell 1994; Jejeebhoy 1995; Strauss and Thomas 1995; and Agha 2000 for a review of infant mortality; and Sathar et al. 1988; Stromquist 1989; and Hill and King 1993 for children's schooling). 
The interpretations of these relationships and the specified pathways through which the researchers argue that education improves a mother's ability to invest in her children's health and schooling are far from consistent, however. Most researchers follow Caldwell's (1979) and Ware's (1984) arguments that maternal education benefits children's survival probabilities through reducing fatalism, increasing a mother's ability to manipulate the world (i.e., improving her ability to seek and secure treatment), and changing the balance of power in family relationships. Improvements in women's status are thus considered to be connected to, and represented by, women's education. However, many of the empirical tests aimed at understanding the pathways through which maternal education affects child health and survival have highlighted the importance of better use of health facilities (Bicego and Boerma 1991; Caldwell and Caldwell 1993); better processing of health information attributed to basic education skills learned in school (Caldwell 1979; Glewwe 1999); and changes in mother's behavior associated with better health practices, such as seeking treatment and providing better child care (Cleland 1990; Caldwell and Caldwell 1993). While these studies suggest better performance by educated mothers, the empirical evidence is far from conclusive (Desai and Alva 1998), and the results do not necessarily speak to a relationship between women's status per se and child survival.

On the other hand, the link between maternal education and children's schooling in South Asia, which has received considerably less systematic research attention, is explained as operating through an increased real or perceived value of women and girls that disrupts substantial male preference; a greater value attached to education (i.e., more positive attitudes toward schooling); and exposure to modern ideas, particularly in the case of daughters' schooling (Sathar et al. 1988). The emphasis is placed more on the increase in abilities and potential economic freedom attributed to educated women and changes in perceptions of the value of educated girls in general as opposed to specific behaviors or events that are associated with it (such as in the case of children's health). Again, while researchers argue that maternal education increases children's schooling, particularly that of girls, because of an improved status of women and girls, the majority of research in the area fails to incorporate measures of women's status in the models (Stash and Morgan 1999 provide an exception). Confounding women's status with 
women's education in this way makes it difficult to determine the relationship of either with investments in children in the form of schooling.

Questions about what women's education indicates in these models are not limited to those regarding women's status. Additional questions have been raised about whether mother's schooling has an independent effect on investments in children or whether it serves merely as a proxy for a household or community's socioeconomic status (United Nations 1993). In analyses of both infant mortality and children's schooling in Pakistan, the household's economic position and father's education are also often significant predictors of investments in children, although, particularly in the case of children's schooling, maternal education generally has a stronger effect (Sathar 1993; Sathar and Lloyd 1994; Durrant 1998; Agha 2000). Most studies support an independent (although often reduced) effect of maternal education on infant and child health and survival after controlling for a household's socioeconomic status (see Strauss and Thomas 1995 for a review; but see Das Gupta 1997 for an exception), although others question the causal nature of the relationship and even suggest that the relationship may be spurious (Desai and Alva 1998). A close link between women's education and women's status is also questioned by Jeffery and Basu (1996) in a review of the relationship between the two and fertility in South Asia; the researchers point out that the education context may be conservative and may reinforce gender attitudes. ${ }^{1}$ Again, the informational and behavioral factors most closely associated with maternal education in these studies could occur independently of women's status. Thus, despite widespread agreement that maternal education improves investments in children, the primary limitation of women's education as a proxy for women's status is its inability to explain pathways of influence.

\section{Women's Employment}

Women's employment is more equivocal than women's education when used as an indicator of women's status in studies of investments in children. This is because women's employment and investments in children are endogenous-both are outcomes

of and contributors to household economic and social status and decisionmaking processes-and thus are more theoretically complex than maternal education. Given this, 
the empirical evidence suggests an ambiguous and nuanced relationship, particularly in the realm of child survival. In most studies there is either no association or a negative association between women's work and infant and child survival after controlling for the socioeconomic status of the household (United Nations 1985), even in areas where it is predominantly poor women who work (Basu and Basu 1991; Kishor and Parasuraman 1998). The negative association is also upheld with macro-level data from India (Kishor 1993).

The most common argument for why women who work experience higher infant and child mortality (controlling for socioeconomic status) is the reduced time that mothers can spend with their infants, possibly confounded by the difficulty of arranging for child care (Basu and Basu 1991; Leslie and Buvinić 1991). Rather than challenging the notion that women's status improves the ability of women to invest in their children, Basu and Basu (1991) argue that this finding shows that working women have additional challenges that detract from or counteract the potential positive effects of their work. In their words, "[I]n the case of actual employment, there appears to be a crucial trade-off between such autonomy and other factors detrimental to child survival" (Basu and Basu 1991: 87). Nevertheless, the conflicting nature of women's employment as it relates to child survival undermines its value as an indicator of women's status. This holds true even when looking at different types of work (i.e., formal- vs. informal-sector work and paid vs. unpaid employment), a strategy that addresses the endogeneity by incorporating women's employment opportunities as opposed to decisions about whether or not to work. Specifically, Kishor and Parasuraman (1998) fail to support their hypothesis that women working outside the home for pay (the most likely to experience increased status through income and exposure to the public sphere) have lower levels of child mortality than women working in other capacities.

Further investigation of sex-specific mortality rates in children provides additional support that the negative association between women's employment outside the home and child survival may be unrelated to the improvement in women's status that may or may not occur with it. Specifically, while studies demonstrate that women's employment is associated with a decrease in excess female mortality or male-biased sex differentials in mortality (Dyson and Moore 1983; Basu and Basu 1991; Kishor 1993; Kishor and Parasuraman 1998), the more equal sex ratios in mortality among children of 
women working outside the home are largely attributed to higher mortality among sons rather than lower mortality among daughters (Kishor and Parasuraman 1998). Thus, rather than supporting the hypothesis that higher-status working women (i.e., those who work for pay outside the home) have lower infant and child mortality rates because they invest more care in their daughters, the empirical results suggest that the sex differential is reduced because women working outside the home are less able to favor their sons (Kishor and Parasuraman 1998).

Although the above examples speak directly to infant and child mortality, it is probable that women's employment also fails to provide a robust indicator of women's status in terms of its effects on children's schooling, especially in rural areas. The positive effects of work (through exposure to opportunities, modern values, and income) are potentially counteracted by a demand for child work in and outside the home that may accompany a mother's work. In societies such as Pakistan where women's work is disproportionately seen in rural areas and among the poor, the fact that a mother is working may reflect a relatively high demand for labor in the area (i.e., during sowing and harvesting seasons) and poverty in the family rather than a positive independent influence on children.

In sum, rather than challenging the notion that women's status is an important agent in investments in children such as those leading to improvements in infant survival and children's schooling, results of studies using women's education and/or employment serve to support the notion that women's status is elusive, multidimensional, and hard to measure. They collectively support the need to look at the effects of different aspects of women's status to understand these complex relationships.

\section{Direct Measures of Women's Status}

The inadequacies of maternal education and employment as indicators of women's status no doubt provided motivation for the growing, but limited, number of studies that incorporate measures of women's status separate from their education and work activity, especially in areas like South Asia where norms of female seclusion are an important aspect of women's status. In the few studies that focus specifically on different measures of women's status and infant mortality and children's schooling, the preliminary 
evidence supports an influence of various dimensions of women's status, including mobility and decisionmaking autonomy, on investments in children.

Jejeebhoy (1998) concentrates on domestic violence as a key indicator and determinant of infant and fetal mortality in rural India. Her findings indicate that women who report being beaten by their husbands have a significantly and substantially higher likelihood of fetal and infant loss. However, her findings show that other aspects of women's status, including decisionmaking (participation in making decisions on purchases of food, jewelry, and major household goods), mobility (opportunity to travel unaccompanied to market, health center, community center, homes of friends, and the next village), and resource control (ability to purchase clothes, jewelry, and gifts without consulting with or getting resources from others), are not significant (with the exception of mobility in Tamil Nadu, which is significant and in the expected direction). Other studies that incorporate measures of women's status specifically related to women's ability to care for their children do indicate the significant effect of women's status (at least autonomy in child-related matters) on infant and child mortality. In a recent study of the relationship between women's status and infant and child mortality in rural Bangladesh, Hossain et al. (2000) incorporate three indexes of women's status (autonomy, decisionmaking authority, and mobility outside the village) and show that higher status scores on the decisionmaking authority index are significantly associated with lower risks of postneonatal, infant, and child mortality. Higher scores on the mother's autonomy index are also associated with reduced risk of post-neonatal mortality. Furthermore, the findings indicate that these results are particularly pronounced for girls. Kishor's (1995) research on Egypt also indicates a positive influence of favorable attitudes toward women's mobility and participation in household decisionmaking on childbearing and child survival; however, multivariate relationships controlling for other factors such as biomaternal characteristics (i.e., birth spacing, age of mother at birth, birth order) and socioeconomic status were not examined.

While these studies point to significant effects of multiple (but varying) aspects of women's status on child outcomes at the individual level, they fail to incorporate macro-level differences in women's status. Thus, we are unable to determine from these results whether the influence of women's decisionmaking authority on infant and child 
survival is driven by the choices of individual women or by an environment (such as a particular village) that supports women's participation in family processes.

Stash and Morgan (1999) support the need to address the influence of micro and macro measures of women's status in their study of women's mobility and children's education in India, Nepal, and Pakistan. While their research supports the notion that higher levels of mothers' mobility (using an index measuring the ability to travel alone and without permission to a health center or clinic, homes of friends and relatives, the local market, fields around the village, and a community center) are associated with a modest but significant increase in the likelihood that both boys and girls between the ages of 10 and 14 years will complete first grade, the mean level of women's mobility at the community level was significantly related to a reduced sex differential in completion of first grade (through an increase in girls' completion) whereas mother's mobility at the individual level was not. The inclusion of community-level measures of women's mobility enhances our understanding of women's status and improves our ability to address gender gaps in schooling in ways that individual measures alone cannot. However, the researchers' focus on women's mobility provides insight into only one aspect of women's status.

The literature suggests a number of reasons to expect differences in the aspects of women's status that are significant for infant mortality and children's schooling. For example, a mother's education can reduce infant mortality through her acquisition of specific information (i.e., that which improves her ability to recognize and/or treat ailments in her children). At the same time, a mother's education can contribute to her children's education, particularly that of daughters, by increasing the real or perceived benefits and value of education and of girls. Other factors besides women's status that are important predictors of each outcome also differ. Biomaternal and environmental factors are paramount in models of infant mortality in developing countries, including Pakistan (Sathar 1987; Irfan 1989; Agha 2000), whereas household composition and community factors are influential determinants of children's schooling in Pakistan (Sathar and Lloyd 1994; Durrant 1998). It is in this difference that we see the benefit of looking at investments in children as opposed to either infant survival or children's schooling. 


\section{DEVELOPMENT OF HYPOTHESES}

In the case of infant mortality, we argue that empowerment of women decreases risk behaviors related to high infant mortality by increasing women's control over reproductive behavior (Kazi and Sathar 1996) and by enabling health-seeking behaviors (Bicego and Boerma 1991; Caldwell and Caldwell 1993). Clearly, in societies where women are the primary providers of care for children, the wellbeing of a young child is closely linked with the wellbeing of his or her mother (Pinnelli 1993). Infants depend on their mothers for their physical situation (i.e., unhealthy mothers are more likely to produce unhealthy children) and care (e.g., proper breastfeeding). As such, factors that improve a woman's ability to care for herself and her newborn children should result in higher levels of infant survival, all other factors held constant. Given this, we would expect certain dimensions of women's status - such as freedom from fear of violence by husbands, freedom of movement, decisionmaking authority (particularly for decisions regarding children), and access to financial resources - to be associated with reduced risk of infant mortality.

For infant survival, factors at the individual level should be more important than macro-level measures of women's status. This is because the factors that generally have the greatest weight in explaining infant mortality in Pakistan (i.e., birth spacing, the age of the mother, and the socioeconomic status of the household) are applicable at the individual and household level. Although availability of a health center in the local area is often a significant factor associated with lower infant and child mortality, the effects of other aspects of communities, including women's employment and education, are less consistent. Because children are valued more or less uniformly throughout Pakistan, improvements in women's status at the individual or household level that enable a mother to better provide a healthy environment for her children supersede any norms that would operate against such behavior.

In contrast to the situation with infant mortality, we expect women's status at the community level to have a stronger influence than an individual woman's status on investments in children's schooling in rural Punjab. Particularly for girls, the tradition of education and the establishment of schools in a community are strong indicators of social values favorable to schooling and a precursor to widespread school attendance (Sathar, Lloyd, 
and Haque 2000). While much of the research on the determinants of children's education in South Asia focuses on household decisionmaking processes that are affected by socioeconomic status and household size and composition (Khan 1993), research has also supported the significance of community factors in Pakistan, including availability of schools (Sathar and Lloyd 1994; Durrant 1998), availability of water and power sources (Durrant 1998), demand for labor (Mahmood, Javaid, and Baig 1994), and women's mobility (Stash and Morgan 1999) in conditioning these effects, particularly in rural areas. Recent research also indicates that both mothers and fathers in Pakistan have high educational aspirations for their sons and daughters (Gazdar 1999; Sathar, Lloyd, and Haque 2000).

The question is thus whether higher levels of women's status improve the ability of mothers to contribute to this investment independent of other household factors. Unlike infant mortality, where the individual actions of women have immediate consequences for their children, children's schooling is likely to be determined by long-term plans and strategies. These, in turn, are more likely to be affected by (and affect) the community's perception of women's and girls' status and social value. We particularly argue that the mobility of women, their participation in the public sphere, and their freedom from fear of disagreeing with their husbands at the community level will improve the likelihood that children, particularly girls, attend school.

In sum, we test four main hypotheses in the remainder of this paper:

(1) Higher levels of different dimensions of women's status are associated with lower levels of infant mortality and higher levels of children's school attendance.

(2) A mother's own status has a greater effect on infant mortality than the level of women's status in general in the community.

(3) Women's status in the community has a greater effect on children's schooling opportunities than a mother's status.

(4) Because women's status indicators at the community level are expected to reflect norms and values favorable to women and girls, this relationship should be stronger for girls' schooling than for boys' schooling.

\section{DATA AND METHODS}

Data are drawn from the Pakistan Status of Women and Fertility (SWAF) Survey conducted in rural Punjab in 1993-94 as part of a five-country SWAF study led by Karen 
Mason and Herbert Smith (with Zeba Sathar as coordinator for the Pakistan survey). Punjab is the most populous province in Pakistan as well as the most diverse. The northern region of the province is characterized by a relatively good economic situation that is related largely to more consistent and productive agriculture, while the southern region is arid, poorer, and more feudal. The sample includes one periurban area. By focusing on rural Punjab the study design was able to sample from a number of different communities where women's status (and other variables) differ, which provided the ability to compare the situation of women in communities with gender norms relatively more or less favorable to women. Selected villages that make up the sampling frame were chosen to incorporate variability in gender systems at the community level in order to facilitate investigation of macrolevel effects of women's status in addition to those at the micro level. The study design and survey are discussed in greater detail in Sathar and Kazi (1997) and Smith et al. (1995).

The SWAF surveys were designed to test the theoretical framework discussed previously. As such, the survey contains a large number of questions on various aspects of women's status, including mobility, decisionmaking, access to economic resources, work activity, participation in various household tasks, gender attitudes, domestic violence, and fear of disagreeing with spouse. Extensive marriage and birth histories, including death and schooling information for children, were also collected for each woman as well as information on the household's socioeconomic status and basic community profiles of the 10 villages in which women were surveyed. Within the selected villages, households were randomly selected. Using household rosters, all women in the household who met the sample criteria were identified; from these, one was randomly selected to complete the full interview. The sample consists of 1,036 currently married women between the ages of 15 and 39 who live in rural Punjab. Interviews were conducted in the local language by trained interviewers. Efforts were made to conduct the interviews in privacy away from others in the household.

The children's sample is drawn from the birth histories of children born to women in the sample. Of the 1,036 women in the original sample, 923 had live births. The sample used in the infant mortality model is restricted to children ever born under the age of 10 who were born at least one year before the survey date. It is further restricted to those from whom complete information on all variables in the model is available and includes 2,316 live births (with about 5 percent lost due to missing information). Al- 
though women's status is the primary focus of this study, it is important to note that our units of analysis are the children of the women in the sample.

We include all children within the targeted age range born to each mother to maximize sample size, particularly because infant mortality is a relatively rare event. A number of recent studies have investigated the effects of family clustering on infant and child deaths due to biological and environmental factors (Guo 1993; Das Gupta 1997; Sastry 1997). Although all support the need to recognize clustering in infant and child mortality models, the results also suggest that the consequences of clustering on models are mitigated by adequate controls for household factors such as socioeconomic status and health environment associated with high levels of mortality (Das Gupta 1997) and by controls at the community level that may otherwise be exhibited in family-level clustering (Sastry 1997). In addition, the effect of clustering is greater on the standard errors than on parameter estimates (Guo 1993). We adjust for the effects of clustering at the household level on the standard errors using the Huber-White correction (Huber 1967; White 1980). In addition, as we include a number of household and community controls, the effects of clustering in our models should be minimized.

The schooling sample $(n=1,406)$ includes living children between the ages of 6 and 15 on whom complete information on all variables is available (again, approximately 5 percent were lost due to missing information). In Pakistan, children are generally expected to enter school by age 6 , and a child who enters school and progresses through in a timely manner will finish secondary schooling at age 15 or 16 . Thus, a sampling frame with these boundaries captures children who potentially could be in school.

\section{Dependent Variables}

The first dependent variable, infant mortality, is measured using a dichotomous variable. Children (or all live births) are coded 1 if they die before the exact age of 12 months and 0 otherwise. To measure children's schooling we create another dependent variable coded 1 if the child has ever attended school and 0 if the child has never attended school. To test our hypotheses we use logistic regression techniques and include a number of variables to capture different dimensions of women's status at both the individual and community levels and appropriate control variables for each outcome. 
Measurement of all variables used in our models is discussed below. A summary of the definitions of all variables used is presented in the appendix.

\section{Measures of Women's Status}

We use six indicators of women's status at the individual level and three at the community level. Although other aspects of women's status are important in their own right, for example, defying gender norms and gender-related attitudes (Balk 1997), we incorporate elements of women's status we consider particularly relevant for investments in children, including aspects of mobility, financial freedom, household decisionmaking, and freedom from coercion (through fear of and abuse by husband). As such, we include measures of women's status independently as well as in relation to husbands. ${ }^{2}$ Because the purpose of the study is to examine direct measures of women's status, we include mother's schooling (whether or not she ever attended school) as a control variable rather than as an indicator of status.

Purdah. Women from conservative households are expected to have lower status than those from more modern households. To capture the conservativeness of the household we use a variable that indicates whether or not the mother responds positively when asked if she practices purdah outside of her home. While purdah literally refers to full or partial veiling, it also reflects observance of female seclusion and practices that restrict the freedom of women and their use of space (Basu 1992). Although our measure is subjective and may represent different degrees of veiling and segregation for different women (as no definition of purdah was given), particularly across communities with different gender norms, we argue that the measure captures the subjugation of a woman in her household according to local norms and is thus comparable across settings (or socioeconomic classes) even if it is exhibited differently. In fact, because purdah takes on different forms based on cultural expectations as well as the economic needs of the household that may influence women's work or participation in the public sphere (Amin 1997), a subjective measure such as this, particularly when used in conjunction with a more objective measure of mobility, may have more validity.

Mobility. Women's freedom of movement is also viewed as particularly crucial in the ability of women in South Asia to promote positive outcomes in their children. Re- 
stricted movement is believed to impair women's ability to keep themselves and their children healthy and to care for those who are sick. Our mobility index sums responses concerning three places to which a woman says she can travel alone and without permission from her spouse or another family member, specifically, the market, a health center, and the homes of friends or relatives. We follow the measurement of Stash and Morgan (1999), but do not include mobility to fields outside the village and the community center because we focus on mobility likely to affect the wellbeing of children rather than mobility in general and exclude places likely to be related to a mother's work status (i.e., fields).

Fear of disagreeing with husband. Another variable assessing a woman's relationship with her husband measures her fear of disagreeing with him. Women who fear to disagree with their husbands are more likely to conform to their husbands' desireswhich symbolizes a woman's compromised ability to act on her own desires. To measure this fear we use a dummy variable, "frequently fear," created using a series of questions that ask whether a woman fears to disagree with her husband and how often. Respondents who report they are often afraid to disagree with their husbands are coded as 1 while those who do not fear or who are only "occasionally" or "sometimes" afraid to disagree are coded as 0 .

Domestic violence. Obviously, women who are beaten by their husbands also have less status because of their lack of control over their bodies. ${ }^{3}$ Their ability to actively participate in decisions regarding their own lives as well as their children's may be compromised through this violence and/or fear of it (Jejeebhoy 1998). We include an ordinal measure of domestic violence by a husband with three possible categories: never beaten (omitted category), sometimes beaten, and regularly beaten.

Access to financial resources. Aspects of women's status that revolve around access to financial resources are common in the discourse on women's status. Particularly in light of the investments in children under examination, which generally involve financial outlays, a woman's ability to secure items and services herself is an important measure of her empowerment. Economic freedom is important in two senses. The first involves the ability of women to secure items and services that they perceive as important in fulfilling personal or family needs (including health care, school fees, and so forth). The second is less tangible and is related to the oft-cited importance of women's 
economic security. We create an index of access to cash resources using responses to two questions. The first asks respondents whether or not they have household money in hand and the second asks whether they own any land, jewelry, or valuables that they can use as they will without permission.

Decisionmaking autonomy on children's issues. The child decisionmaking autonomy index involves a woman's participation in decisions regarding children similar to Kishor's (1995) customary autonomy index. Specifically, this measure involves a woman's participation in decisions about what to do with a sick child, whether to punish a child, and the amount and type of schooling for children. Two questions related to children asked in the same sequence of questions were excluded. A question about who decides when a child will marry was not included in this index because children's marriage is largely regarded as an economic decision rather than as a decision about the interests of the child (Jejeebhoy 1995). Another question about who decides the number of children a woman will have was excluded because of its possible endogeneity with infant mortality (as families' experiences with infant mortality affect their fertility desires and behavior).

The aspects of women's status included in our models and the construction of indexes were determined on theoretical grounds; however, a factor analysis test (specified to six factors and with varimax rotation applied) generally confirmed the validity of our indexes and the use of the other variables as distinct variables (i.e., high uniqueness values). ${ }^{4}$

Community-level gender norms. To measure women's status at the community level we took the mean of all women in each of the 10 villages on each of these variables, excluding the respondent, and constructed a community measure of women's work outside the home to indicate the level of women's participation in the public sphere and the gender division of the work force in the community (this variable was not included at the individual level due to endogeneity issues). However, correlation coefficients indicated that a number of these aggregated variables were highly associated. To avoid problems with multicollinearity in our multivariate models, we selected three indicators of women's status at the community level we think have theoretical importance for the outcome variables and that demonstrate low levels of correlation. These three 
variables are the community mobility index (the mean mobility for women in the community), the percentage of women in the community working outside the home, and the percentage of women in the community who report that they often fear to disagree with their husbands, excluding the respondent. Once aggregated, the meanings attributed to these variables change somewhat, reflecting community gender norms rather than individual actions (Balk 1997; Stash and Morgan 1999). For example, while at the individual level a woman's mobility indicates her ability to acquire goods and services for her children, the community mean of mobility more likely reflects the acceptance of women moving in the public sphere. The percentage of those who often fear to disagree with their husbands reflects compliance with patriarchal and repressive norms in the community.

As demonstrated in Table 1, there is variability in the measures of women's status across the 10 villages sampled in rural Punjab. ${ }^{5}$ The mean of the women's mobility index ranges from 0.24 in Dab to 0.94 in Faisalabad Chak. Women in Kot Soondki as a whole do not fear to disagree with their husbands, as only 11 percent report they are frequently afraid to do so. At the other end of the range, 47 percent of women in Ali Kharak report often being afraid to disagree with their husbands. The percentage of women in each village who work outside the home is also shown with figures ranging from 24 percent in Rakh Kikrian to 87 percent in Ali Kharak. It is important to note the variation in women's status relative to other villages at the community level by indicator. No village exhibits the highest or lowest value of women's status for more than a single variable. Further, many of the villages exhibit values representing higher levels of gender norms favorable to women on some indicators and lower relative levels on others. This speaks to the importance of using multiple indicators and carefully choosing the indicator of women's status by the dimension being measured.

As with all studies, there are limitations in our investigation of women's status and investments in children. The most serious limitation of our study is associated with the assumptions necessitated by the cross-sectional nature of our data, specifically that our measures of women's status were applicable to decisions and behaviors that took place up to 10 years prior to the survey. This is particularly problematic in examining a relationship like women's status and investment in children (particularly infant mortal- 
Table 1 Descriptions of community-level women's status measures, by village, rural Punjab

\begin{tabular}{|c|c|c|c|c|}
\hline \multirow[b]{2}{*}{ Region/Village } & \multirow[b]{2}{*}{$\begin{array}{l}\text { No. of women } \\
\text { in community }\end{array}$} & \multicolumn{3}{|c|}{ Community-level women's status indicators ${ }^{a}$} \\
\hline & & $\begin{array}{c}\text { Mobility } \\
\text { (index mean) }\end{array}$ & $\begin{array}{c}\% \text { worked } \\
\text { outside home } \\
\text { in past year }\end{array}$ & $\begin{array}{l}\% \text { frequently } \\
\text { afraid to } \\
\text { disagree } \\
\text { with husband }\end{array}$ \\
\hline Total & 1,036 & 0.66 & 56.4 & 30.3 \\
\hline $\begin{array}{l}\text { Northern, rainfed } \\
\text { Kot Soondki } \\
\text { Samote } \\
\text { Khokar Bala }\end{array}$ & $\begin{array}{r}78 \\
108 \\
102\end{array}$ & $\begin{array}{l}0.86 \\
0.50 \\
0.69\end{array}$ & $\begin{array}{l}57.1 \\
75.0 \\
78.4\end{array}$ & $\begin{array}{l}10.5 \\
13.9 \\
36.1\end{array}$ \\
\hline $\begin{array}{l}\text { Northern, semi-irri } \\
\text { Dab } \\
\text { Beerbal }\end{array}$ & $\begin{array}{l}101 \\
101\end{array}$ & $\begin{array}{l}0.24 \\
0.66\end{array}$ & $\begin{array}{l}36.3 \\
58.2\end{array}$ & $\begin{array}{l}26.0 \\
24.0\end{array}$ \\
\hline $\begin{array}{l}\text { Periurban } \\
\quad \text { Rakh Kikrian }\end{array}$ & 102 & 0.89 & 23.6 & 33.8 \\
\hline $\begin{array}{c}\text { Central, irrigated } \\
\text { Faisalabad Chak } \\
\text { Sahiwal Chak }\end{array}$ & $\begin{array}{l}103 \\
100\end{array}$ & $\begin{array}{l}0.94 \\
0.72\end{array}$ & $\begin{array}{l}50.0 \\
68.4\end{array}$ & $\begin{array}{l}24.2 \\
37.8\end{array}$ \\
\hline $\begin{array}{l}\text { Southern } \\
\text { Boshin } \\
\text { Ali Kharak }\end{array}$ & $\begin{array}{l}131 \\
110\end{array}$ & $\begin{array}{l}0.46 \\
0.60\end{array}$ & $\begin{array}{l}45.1 \\
86.7\end{array}$ & $\begin{array}{l}36.8 \\
46.6\end{array}$ \\
\hline
\end{tabular}

${ }^{a}$ Community means are calculated for the full number of married women in the sample and not simply those with children.

ity) that may operate in both directions (Mason 1993). In other words, just as it is likely that women with higher levels of mobility, access to resources, and autonomy can better care for their children, it is also possible that women are rewarded for successful birth and child survival histories in a pronatalist culture like that of rural Pakistan. The variable with the highest likelihood of reverse causality may be abuse of the mother by the husband. Children of women who are regularly beaten by their husbands face greater risks to their survival (Jejeebhoy 1998). On the other hand, women who prove "unsuccessful" in their role as mothers (exhibited by an infant death) may become subject to physical abuse. We recognize that our inability to assess the direction of causality in this study constrains our interpretations and policy recommendations and reiterates the need for future research using data that enable us to sort out the causal nature of these rela- 
tionships. However, given that the majority of births in the infant mortality sample occurred within a few years of the survey, and that there is very little difference in women's status between the infant mortality and child schooling samples (or across women of different ages), it is unlikely that this poses a serious problem in our results. We take additional steps, discussed in the results section, to address this issue.

\section{MODELS}

\section{Infant Mortality}

To fully understand the relationship between women's status and our outcomes we need to control for a number of other factors. Our main hypotheses about women's status and infant mortality are that multiple elements of women's status will be important-particularly mother's mobility, access to financial resources, decisionmaking autonomy on matters related to children, and freedom from abuse by her husband-and that individual-level factors are more important than community-level indicators of gender norms favorable to women. To adequately test these hypotheses we must control for a number of other factors, particularly biomaternal characteristics, the socioeconomic status of the household, and the availability of proximate health services. Specifically, infant mortality tends to be higher among children born to younger or older mothers (Hobcraft, McDonald, and Rutstein 1985; Sathar 1987), among firstborn children, among those with a short interval since the preceding birth (Hobcraft, McDonald, and Rutstein 1983, 1985; Sathar 1987; Koenig et al. 1990; Boerma and Bicego 1992; Curtis, Diamond, and McDonald 1993), ${ }^{6}$ among children born to mothers who have experienced a previous infant death (Curtis, Diamond, and McDonald 1993; Guo 1993; Sastry 1997), and among children born to consanguineous marriage partners (Bittles, Grant, and Shami 1993; Shah, Toney, and Pitcher 1998). ${ }^{7}$ We include measures of mother's age at birth (under age 20, age 20-34, age 35 or higher), birth order of children (1, 2-4, 5 or higher), preceding birth intervals less than 24 months, whether the mother has experienced a previous infant death, and whether the mother and father are blood relatives.

A number of studies document the importance of a household's socioeconomic status as indicated by income, possessions, housing materials and resources, and parents' education (Hobcraft, McDonald, and Rutstein 1984; Sathar 1987, 1995; Das Gupta 
1997; Agha 2000). We include a categorical variable of the father's highest level of completed education, including categories for no education (the omitted category), 1-4 years, 5-7 years, or 8 or more years of schooling; and a measure of total household income per adult equivalent (logged). We also include a dichotomous variable indicating whether the household owns any land and an index measuring possession of nonelectrical household appliances. Other dichotomous variables indicate whether or not the household is nuclear and whether the mother ever attended school. At the community level we include a variable measuring the distance to the nearest health facility in kilometers. All variables are defined in the appendix, and the sample distributions are presented in Table 2.

\section{Children's Schooling}

For children's schooling, we expect the community-level indicators of women's status to be more influential in explaining whether or not children ever attend school. The majority of studies that address children's schooling in South Asia focus on individual- and household-level factors. Specifically, the size, structure, and socioeconomic status of the household, in addition to factors at the individual level including sex, age, and number of siblings, are the common explanatory variables used in studies of children's education (for a review see Khan 1993; Sathar and Lloyd 1994; and Durrant 1998). To capture these important influences we include measures of the child's sex, age in years, birth order category, total number of live children, and whether the child's household is nuclear or not. We include the same three measures of a household's socioeconomic status (adjusted household income, land ownership, and possession of nonelectrical appliances) and the parental education variables that are used in the infant mortality model.

Recent research on children's schooling in Pakistan points to the importance of community factors, including school availability and other resources of the larger community (Sathar and Lloyd 1994; Durrant 1998). We include a community-level measure of the availability of a middle school in the village. All villages in our sample have a boys' and girls' primary school. ${ }^{8}$ Although schools are usually sex-segregated in Pakistan and boys' schools are more widespread than girls' schools, particularly in rural areas (Government of Pakistan 1997; Gazdar 1999), we are unable to differentiate be- 
Table 2 Sample distributions (means for continuous variables with standard deviations in parentheses) for variables used, infant mortality and schooling samples, rural Punjab

\begin{tabular}{lccc}
\hline Variable & $\begin{array}{c}\text { Categories } \\
\text { (if applicable) }\end{array}$ & $\begin{array}{c}\text { Infant mortality } \\
\text { sample }\end{array}$ & $\begin{array}{c}\text { Schooling } \\
\text { sample }\end{array}$ \\
\hline Infant mortality & Yes & $11 \%$ & - \\
Ever attended school & No & $89 \%$ & - \\
& Yes & - & $70 \%$ \\
Individual-level women's status & No & - & $30 \%$ \\
Purdah outside home & & & \\
& Yes & $37 \%$ & $31 \%$ \\
Mobility & No & $63 \%$ & $69 \%$ \\
Fear of husband & Continuous, 0-6 & $2.04(1.98)$ & $2.24(2.00)$ \\
& Yes & $32 \%$ & $29 \%$ \\
Domestic violence & No & $68 \%$ & $71 \%$ \\
& Never & $58 \%$ & $57 \%$ \\
Access to financial resources & Sometimes & $33 \%$ & $35 \%$ \\
Decisionmaking in regard to children & Regularly & $9 \%$ & $8 \%$ \\
Community-level women's status & Continuous, 0-2 & $1.32(0.68)$ & $1.33(0.66)$ \\
Mobility & Continuous, 0-4 & $1.38(1.32)$ & $1.48(1.33)$ \\
Work outside home & & & \\
Fear of husband & Continuous, 0-6 & \\
\hline & Continuous, 0-100 & $1.71(0.56)$ & $1.73(0.55)$ \\
& Continuous, 0-100 & $0.52(0.21)$ & $0.52(0.22)$ \\
& & & $0.29(0.10)$ \\
\hline
\end{tabular}

tween a boys' and girls' school at this level due to missing information on the availability of a girls' school for one of the villages (Beerbal). However, this is the only village where the response to this measure may have differed for boys and girls (i.e., all others had either a boys' and girls' middle school in the village or neither). Research in Pakistan also highlights the importance of school quality in determining attendance (Gazdar 1999; Sathar, Lloyd, and Haque 2000); however, we are unable to control for this. Again, the definitions are summarized in the appendix and sample distributions presented in Table 2.

\section{FINDINGS}

\section{Women's Status in Rural Punjab}

According to the figures in Table 2, women in rural Punjab exhibit generally low status. Thirty-seven percent of children in the infant mortality sample have mothers who practice purdah outside the home, 32 percent have mothers who express a lot of fear 
Table 2 (continued)

\begin{tabular}{|c|c|c|c|}
\hline Variable & $\begin{array}{c}\text { Categories } \\
\text { (if applicable) }\end{array}$ & $\begin{array}{c}\text { Infant mortality } \\
\text { sample }\end{array}$ & $\begin{array}{c}\text { Schooling } \\
\text { sample }\end{array}$ \\
\hline \multicolumn{4}{|l|}{ Control variables } \\
\hline \multirow[t]{2}{*}{ Sex of child } & Boy & $51 \%$ & $51 \%$ \\
\hline & Girl & $49 \%$ & $49 \%$ \\
\hline \multirow[t]{3}{*}{ Birth order } & 1 & $20 \%$ & $27 \%$ \\
\hline & $2-4$ & $50 \%$ & $56 \%$ \\
\hline & $5+$ & $30 \%$ & $17 \%$ \\
\hline \multirow[t]{2}{*}{ Previous infant death in family } & Yes & $22 \%$ & n.a. \\
\hline & No & $78 \%$ & n.a. \\
\hline \multirow[t]{2}{*}{ Short preceding birth interval } & Yes & $39 \%$ & n.a. \\
\hline & No & $61 \%$ & n.a. \\
\hline \multirow[t]{3}{*}{ Age of mother at birth of child (years) } & $<20$ & $15 \%$ & n.a. \\
\hline & $20-34$ & $82 \%$ & n.a. \\
\hline & $35+$ & $3 \%$ & n.a. \\
\hline \multirow[t]{2}{*}{ Husband is blood relative } & Yes & $80 \%$ & n.a. \\
\hline & No & $20 \%$ & n.a. \\
\hline \multirow[t]{2}{*}{ Nuclear household } & Yes & $54 \%$ & $63 \%$ \\
\hline & No & $46 \%$ & $37 \%$ \\
\hline Live children & Continuous & n.a. & $5.23(1.80)$ \\
\hline \multicolumn{4}{|l|}{ Total household income } \\
\hline per adult equivalent (logged) & Continuous & $8.45(0.83)$ & $8.41(0.91)$ \\
\hline \multirow[t]{4}{*}{ Father's educational attainment } & None & $44 \%$ & $41 \%$ \\
\hline & $1-4$ years & $8 \%$ & $7 \%$ \\
\hline & $5-7$ years & $18 \%$ & $19 \%$ \\
\hline & $8+$ years & $31 \%$ & $33 \%$ \\
\hline \multirow[t]{2}{*}{ Mother ever attended school } & Yes & $16 \%$ & $17 \%$ \\
\hline & No & $84 \%$ & $83 \%$ \\
\hline \multirow[t]{2}{*}{ Household owns land } & Yes & $58 \%$ & $56 \%$ \\
\hline & No & $42 \%$ & $44 \%$ \\
\hline Index of nonelectrical possessions & Continuous, $0-4^{\mathrm{a}}$ & $2.42(1.21)$ & $2.45(1.21)$ \\
\hline Distance to health facility (kilometers) & Continuous & $4.74(3.99)$ & n.a. \\
\hline \multirow[t]{2}{*}{ Middle school in village } & Yes & n.a. & 38 \\
\hline & No & n.a. & 62 \\
\hline Mother's age ${ }^{b}$ & Continuous & $30.35(5.30)$ & $33.22(4.29)$ \\
\hline $\mathrm{N}$ & & 2,316 & 1,406 \\
\hline
\end{tabular}

n.a. = not applicable.

${ }^{a}$ Range indicates possible range.

${ }^{\mathrm{b}}$ We present mother's age at the time of the survey to describe the two samples; however, it is not an independent variable used in the models.

about disagreeing with their husbands, and 42 percent have mothers who have ever been beaten by their husbands ( 33 percent sometimes beaten and 9 percent regularly beaten). Mothers' mean level of mobility is also low, with a mean on the mobility index of 2.04 
(possible range, 0-6). Similarly, the mothers of children in the infant mortality sample have little autonomy in decisions about their children with a mean of 1.38 (possible range, $0-4)$. On the other hand, over half of the children in the infant mortality sample have mothers with access to financial resources showing a mean of 1.32 on the access to financial resources index (possible range, $0-2$ ).

The figures for women's status among children in the schooling sample are similar. However, it is worth noting two important (and expected) differences in the samples. First, mothers of children in the schooling sample are almost three years older on average than mothers of children in the infant mortality sample. Second, children in the schooling sample are more likely to live in nuclear households than children in the infant mortality sample. Both of these findings are in accordance with the age ranges of children in the sample according to the criteria for each. In addition, children in the schooling sample have mothers with slightly higher status than children in the infant mortality sample. Again, this corresponds with expectations that women's status increases with age and that married women in nuclear families have higher status than married women in extended families (at least among those with children in our age range).

The descriptive statistics support the view that women's status is multidimensional and has considerable built-in variation across families and communities. Pearson's correlation coefficients of the bivariate relationship among the various individual-level measures and the community-level measures are all under 0.3 in both samples, providing further support that our indicators capture different aspects of women's status. Not surprisingly, the correlations between the community indicators and some of the individual indicators are slightly higher, although none of the correlations exceeds 0.4 in either sample.

\section{Infant Mortality and Children's Schooling}

The levels of infant mortality and children's schooling across the 10 villages are presented in Table 3. While the overall level of infant mortality in our sample of rural Punjab is quite high (11 percent of births in the sampling frame resulted in death before the age of one), there is a lot of variation across the 10 villages. In general, the lowest levels of infant mortality are seen in the northern villages of Dab (8 percent), Khokar Bala 
Table 3 Percentage of infants who died prior to age 12 months and children ever attending school (by sex), by village, rural Punjab

\begin{tabular}{|c|c|c|c|c|c|c|c|}
\hline \multirow[b]{2}{*}{ Region/Village } & \multirow{2}{*}{$\begin{array}{c}\text { Total n, } \\
\text { infant } \\
\text { mortality } \\
\text { sample } \\
\end{array}$} & \multirow{2}{*}{$\begin{array}{l}\% \text { infants } \\
\text { who died } \\
\text { prior to } \\
12 \text { months } \\
\end{array}$} & \multirow{2}{*}{$\begin{array}{l}\text { Total n, } \\
\text { child } \\
\text { schooling } \\
\text { sample } \\
\end{array}$} & \multicolumn{4}{|c|}{$\%$ children ever attending school } \\
\hline & & & & Total & Boys & Girls & F/M ratio \\
\hline Total & 2,316 & 11.1 & 1,406 & 70.1 & 78.9 & 61.1 & 0.77 \\
\hline $\begin{array}{l}\text { Northern, rainfed } \\
\text { Kot Soondki } \\
\text { Samote } \\
\text { Khokar Bala }\end{array}$ & $\begin{array}{l}156 \\
182 \\
183\end{array}$ & $\begin{array}{r}13.5 \\
7.1 \\
7.7\end{array}$ & $\begin{array}{r}90 \\
129 \\
145\end{array}$ & $\begin{array}{l}76.7 \\
77.5 \\
85.5\end{array}$ & $\begin{array}{l}79.5 \\
88.5 \\
96.2\end{array}$ & $\begin{array}{l}74.5 \\
67.8 \\
73.1\end{array}$ & $\begin{array}{l}0.94 \\
0.77 \\
0.76\end{array}$ \\
\hline $\begin{array}{l}\text { Northern, semi-irri } \\
\quad \text { Dab } \\
\text { Beerbal }\end{array}$ & $\begin{array}{l}245 \\
208\end{array}$ & $\begin{array}{l}7.8 \\
9.1\end{array}$ & $\begin{array}{r}143 \\
99\end{array}$ & $\begin{array}{l}86.7 \\
65.7\end{array}$ & $\begin{array}{l}94.0 \\
79.2\end{array}$ & $\begin{array}{l}80.3 \\
52.9\end{array}$ & $\begin{array}{l}0.85 \\
0.67\end{array}$ \\
\hline $\begin{array}{l}\text { Periurban } \\
\text { Rakh Kikrian }\end{array}$ & 276 & 9.4 & 198 & 73.2 & 72.8 & 73.6 & 1.01 \\
\hline $\begin{array}{l}\text { Central, irrigated } \\
\text { Faisalabad Chak } \\
\text { Sahiwal Chak }\end{array}$ & $\begin{array}{l}262 \\
235\end{array}$ & $\begin{array}{r}14.5 \\
7.7\end{array}$ & $\begin{array}{l}136 \\
161\end{array}$ & $\begin{array}{l}65.4 \\
85.1\end{array}$ & $\begin{array}{l}76.8 \\
89.3\end{array}$ & $\begin{array}{l}53.7 \\
80.5\end{array}$ & $\begin{array}{l}0.70 \\
0.90\end{array}$ \\
\hline $\begin{array}{l}\text { Southern } \\
\text { Boshin } \\
\text { Ali Kharak }\end{array}$ & $\begin{array}{l}315 \\
254\end{array}$ & $\begin{array}{l}15.6 \\
16.1\end{array}$ & $\begin{array}{l}171 \\
134\end{array}$ & $\begin{array}{l}52.6 \\
30.6\end{array}$ & $\begin{array}{l}75.3 \\
41.6\end{array}$ & $\begin{array}{l}23.0 \\
15.8\end{array}$ & $\begin{array}{l}0.31 \\
0.38\end{array}$ \\
\hline
\end{tabular}

(8 percent), and Samote (7 percent) whereas the levels seen in the southern villages of Ali Kharak and Boshin (16 percent) are twice as high. For the most part, there seems to be a spatial pattern associated with infant mortality (lowest in the north; low, but slightly higher in the central region; and highest in the south) with the exception of two outliers: Kot Soondki in the north (14 percent) and Sahiwal Chak in the central region (8 percent). Stark differences between north and south Punjab were also identified in the Pakistan Integrated Household Survey (PIHS) data of 1990-91 (World Bank 1995).

There is also considerable variation in the levels of school attendance throughout the province. The percentage of children ever attending school ranges from 31 percent in Ali Kharak to 87 percent in Dab. Seventy percent of children in the overall sample have ever attended school. Unlike infant mortality, there does not appear to be a spatial pattern of school attendance. The percentage of boys and girls who ever attend school in each village is also shown separately. Not only is there significant variation in the per- 
centage of boys and girls who ever attend school in these 10 villages, there is also considerable difference in the gender differences in school attendance as demonstrated by the female-to-male ratios. In the periurban area of Rakh Kikrian, an equal percentage of boys and girls ever attend school, whereas in Boshin three times as many boys as girls (75 percent vs. 23 percent) have ever attended school. Once more these findings were corroborated by the World Bank poverty study using 1990-91 PIHS data (World Bank 1995).

As the table indicates, there is a lack of strong correspondence between infant mortality and children's schooling at the community level. Although the three villages with the highest levels of infant mortality also have the lowest levels of children's school attendance, this pattern does not hold in the other villages. Samote, with the lowest infant mortality, has the fourth highest percentage of children ever attending school. Dab, the village exhibiting the highest percentage of children ever attending school, has the fourth lowest level of infant mortality. This result challenges the possibility that community-level conditions such as socioeconomic status drive both outcomes.

\section{Multivariate Results}

Infant mortality model. The logistic regression odds ratios for the infant mortality model are presented in Table 4. In the first model, which includes the control and individual-level women's status variables, three indicators of women's status are statistically significant at the 0.05 level: mother practices purdah outside home, mother regularly beaten by husband, and mother's access to financial resources. Specifically, the data indicate that children with mothers who practice purdah outside the home are 1.5 times more likely to die before they are 12 months old than those with mothers who do not practice purdah outside the home. Children of mothers who are regularly beaten by their husbands are 1.7 times more likely to die before they reach the age of 12 months than those of mothers who are never beaten. Finally, each one unit increase in mother's access to financial resources is associated with a 0.8 reduction in the likelihood of experiencing infant mortality. The multivariate results thus indicate that multiple dimensions of women's status are important factors related to infant mortality. However, two of the factors we hypothesized to be particularly important were not significant. The odds ratios for mother's mobility and decisionmaking autonomy on child-related issues dem- 
onstrate weak effects that are not statistically significant. Hossain et al. (2000) also fail to find a significant relationship between mother's mobility and infant and child survival in rural Bangladesh. Because women's physical mobility is closely linked to social class in the region, the measure of mobility employed in this study may fail to adequately capture freedom of movement (distinct from social class) that we imply in our model. ${ }^{9}$

When we add the indicators for women's status at the community level in model 2 , none are statistically significant and the addition fails to improve the explanatory power of the model or affect the significance of the individual variables from the previous model. The data support our hypothesis that women's status at the individual level has a stronger relationship to infant mortality than women's status at the community level.

In addition to the individual-level women's status factors mentioned above, birth order, preceding birth interval, and father's education are all significant predictors of infant mortality in the expected direction. In fact, short preceding birth intervals have by far the strongest effect of all variables in the model on infant mortality, increasing the likelihood by over three times. However, we find no significant effect of a mother's schooling on infant mortality in rural Punjab, controlling for other household and community factors, including women's status.

In order to address the potential limitations of our survey due to the time discrepancy in our measures of women's status and infant mortality discussed above, we provide two additional models. In models 3 and 4 we include a dummy variable indicating a spousal age difference of five years or more for the mother instead of the other individual-level women's status variables. Spousal age difference, commonly used as a proxy for women's status in studies where more precise measures are not available (see, for example, Cain 1993 and Uchudi 2000), does not vary over time and thus is not subject to the same concerns as our other indicators. The results from these models, with spousal age difference demonstrating a positive and significant effect on infant mortality, are in accordance with the previous models and provide additional support for our hypothesis.

School attendance. The results from the logistic regression analysis of children's school attendance are shown in Table 5. Contrary to the infant mortality results, none of the individual-level women's status variables is statistically significant in the child schooling model, controlling for other individual, household, and community-level factors 
Table 4 Logistic regression results (odds ratios) for infant mortality model, rural Punjab

\begin{tabular}{|c|c|c|c|c|c|c|c|c|}
\hline \multirow[b]{2}{*}{ Variable } & \multicolumn{2}{|c|}{ Model 1} & \multicolumn{2}{|c|}{ Model 2} & \multicolumn{2}{|c|}{ Model 3} & \multicolumn{2}{|c|}{ Model 4} \\
\hline & $\begin{array}{l}\text { Odds } \\
\text { ratio }\end{array}$ & S.E. & $\begin{array}{l}\text { Odds } \\
\text { ratio }\end{array}$ & S.E. & $\begin{array}{l}\text { Odds } \\
\text { ratio }\end{array}$ & S.E. & $\begin{array}{l}\text { Odds } \\
\text { ratio }\end{array}$ & S.E. \\
\hline \multicolumn{9}{|l|}{ Child characteristics } \\
\hline Boy & 1.086 & 0.159 & 1.084 & 0.159 & 1.060 & 0.153 & 1.060 & 0.153 \\
\hline \multicolumn{9}{|l|}{ Birth order (1 omitted) } \\
\hline $2-4$ & $0.503 * *$ & 0.125 & $0.500 * *$ & 0.124 & $0.502 * *$ & 0.125 & $0.502 * *$ & 0.125 \\
\hline $5+$ & $0.515^{*}$ & 0.144 & $0.511 *$ & 0.143 & $0.504 *$ & 0.144 & $0.504 *$ & 0.145 \\
\hline \multicolumn{9}{|l|}{ Biomaternal characteristics } \\
\hline $\begin{array}{l}\text { Previous infant death } \\
\text { in family }\end{array}$ & 1.374 & 0.243 & 1.371 & 0.245 & $1.472 *$ & 0.262 & $1.470 *$ & 0.262 \\
\hline Short preceding birth interval & $3.341 * *$ & 0.598 & $3.374 * *$ & 0.604 & $3.320 * *$ & 0.585 & $3.329 * *$ & 0.588 \\
\hline \multicolumn{9}{|l|}{$\begin{array}{l}\text { Age of mother at birth of } \\
\text { child ( } 20-34 \text { years omitted) }\end{array}$} \\
\hline$<20$ & 1.226 & 0.260 & 1.219 & 0.254 & 1.264 & 0.263 & 1.263 & 0.262 \\
\hline $35+$ & 1.134 & 0.482 & 1.130 & 0.482 & 1.217 & 0.506 & 1.219 & 0.509 \\
\hline Husband is blood relative & 1.386 & 0.300 & 1.380 & 0.301 & 1.286 & 0.259 & 1.286 & 0.261 \\
\hline \multicolumn{9}{|l|}{ Household characteristics } \\
\hline \multicolumn{9}{|l|}{ Total household income per } \\
\hline \multicolumn{9}{|l|}{$\begin{array}{l}\text { Father's educational attainment } \\
\text { (None omitted) }\end{array}$} \\
\hline $1-4$ years & 0.654 & 0.175 & 0.647 & 0.175 & 0.682 & 0.180 & 0.674 & 0.182 \\
\hline $5-7$ years & 0.690 & 0.151 & 0.687 & 0.152 & 0.727 & 0.154 & 0.722 & 0.155 \\
\hline $8+$ years & $0.624 *$ & 0.148 & $0.614^{*}$ & 0.149 & $0.621 *$ & 0.148 & $0.615^{*}$ & 0.151 \\
\hline Household owns land & 0.900 & 0.149 & 0.859 & 0.157 & 0.847 & 0.138 & 0.841 & 0.153 \\
\hline Index of nonelectrical & & & & & & & & \\
\hline possessions & 0.931 & 0.072 & 0.940 & 0.075 & 0.921 & 0.074 & 0.920 & 0.076 \\
\hline Nuclear household & 0.989 & 0.176 & 0.996 & 0.179 & 0.925 & 0.153 & 0.924 & 0.156 \\
\hline Mother ever attended school & 1.180 & 0.277 & 1.173 & 0.272 & 1.227 & 0.289 & 1.229 & 0.287 \\
\hline
\end{tabular}

(model 1). However, as seen in the second model, two of the three community-level women's status variables demonstrate statistically significant effects. Each unit increase in the mean level of women's mobility in the community increases a child's likelihood of ever attending school 1.6 times. In addition, children are less likely to ever attend school in communities where a higher percentage of women in the community express fear to disagree with their husbands. Thus, the data support our hypothesis that women's status at the community level, or a gender milieu favorable to women, will have a greater effect on children's schooling than an individual mother's empowerment. Further, in- 
Table 4 (continued)

\begin{tabular}{|c|c|c|c|c|c|c|c|c|}
\hline \multirow[b]{2}{*}{ Variable } & \multicolumn{2}{|c|}{ Model 1} & \multicolumn{2}{|c|}{ Model 2} & \multicolumn{2}{|c|}{ Model 3} & \multicolumn{2}{|c|}{ Model 4} \\
\hline & $\begin{array}{l}\text { Odds } \\
\text { ratio } \\
\end{array}$ & S.E. & $\begin{array}{l}\text { Odds } \\
\text { ratio }\end{array}$ & S.E. & $\begin{array}{l}\text { Odds } \\
\text { ratio }\end{array}$ & S.E. & $\begin{array}{l}\text { Odds } \\
\text { ratio }\end{array}$ & S.E. \\
\hline \multicolumn{9}{|l|}{ Community health environment } \\
\hline \multicolumn{9}{|l|}{ Individual-level women's status } \\
\hline Purdah outside home & $1.450 *$ & 0.242 & $1.456^{*}$ & 0.242 & & & & \\
\hline Mobility & 1.038 & 0.040 & 1.043 & 0.041 & & & & \\
\hline Fear of husband & 1.187 & 0.185 & 1.195 & 0.187 & & & & \\
\hline \multicolumn{9}{|l|}{$\begin{array}{l}\text { Domestic violence } \\
\quad(\text { Never beaten omitted })\end{array}$} \\
\hline Sometimes beaten & 0.997 & 0.167 & 1.011 & 0.171 & & & & \\
\hline Regularly beaten & $1.737 *$ & 0.403 & $1.768^{*}$ & 0.412 & & & & \\
\hline Access to financial resources & $0.795 *$ & 0.084 & $0.793 *$ & 0.084 & & & & \\
\hline $\begin{array}{l}\text { Decisionmaking in regard } \\
\text { to children }\end{array}$ & 0.995 & 0.059 & 1.002 & 0.060 & & & & \\
\hline Spouse is older $(5+$ years $)$ & & & & & $1.433 *$ & 0.222 & $1.432 *$ & 0.221 \\
\hline \multicolumn{9}{|l|}{ Community-level women's status } \\
\hline Mobility & & & 0.921 & 0.200 & & & 0.959 & 0.200 \\
\hline Work outside home & & & 1.262 & 0.540 & & & 1.006 & 0.410 \\
\hline Fear of husband & & & 0.736 & 0.534 & & & 0.809 & 0.609 \\
\hline Log likelihood & \multicolumn{2}{|c|}{-753.59} & \multicolumn{2}{|c|}{-753.21} & \multicolumn{2}{|c|}{-760.08} & \multicolumn{2}{|c|}{-759.96} \\
\hline Degrees of freedom & \multicolumn{2}{|c|}{24} & \multicolumn{2}{|c|}{27} & \multicolumn{2}{|c|}{18} & \multicolumn{2}{|c|}{21} \\
\hline
\end{tabular}

Note: $\mathrm{N}=2,316$. Standard errors (S.E.) are adjusted for clustering at the household level using Huber-White correction.

$* * \mathrm{p}<0.01 ; * \mathrm{p}<0.05$

cluding the community-level women's status variables significantly affects the negative log likelihood of the model.

In addition to the community status of women, other factors are significantly associated with children's school attendance in model 2. Boys are 3.8 times more likely to ever attend school than girls, controlling for other variables in the model. In addition, birth order, father's education, mother's education, and ownership of land and nonelectrical appliances are significant predictors of children's school attendance. Higher order children, particularly children over the order of 4, are less likely to ever attend school than first-born children. The likelihood that a child will ever attend school also increases with each level of father's educational attendance, although only those with fathers who have higher than primary-level schooling are significantly different from children with 
Table 5 Logistic regression results (odds ratios) for model of children ever attending school, rural Punjab

\begin{tabular}{|c|c|c|c|c|c|c|c|c|}
\hline \multirow[b]{2}{*}{ Variable } & \multicolumn{2}{|c|}{ Model 1} & \multicolumn{2}{|c|}{ Model 2} & \multicolumn{2}{|c|}{ Model 3} & \multicolumn{2}{|c|}{ Model 4} \\
\hline & $\begin{array}{l}\text { Odds } \\
\text { ratio }\end{array}$ & S.E. & $\begin{array}{l}\text { Odds } \\
\text { ratio }\end{array}$ & S.E. & $\begin{array}{l}\text { Odds } \\
\text { ratio }\end{array}$ & S.E. & $\begin{array}{l}\text { Odds } \\
\text { ratio }\end{array}$ & S.E. \\
\hline \multicolumn{9}{|l|}{ Child characteristics } \\
\hline Boy & $3.573 * *$ & 0.543 & $3.816^{* *}$ & 0.587 & $3.849 * *$ & 0.590 & $3.592 * *$ & 0.542 \\
\hline Age & 1.029 & 0.031 & 1.039 & 0.031 & 1.035 & 0.031 & 1.027 & 0.030 \\
\hline \multicolumn{9}{|l|}{ Birth order (1 omitted) } \\
\hline $2-4$ & $0.596 * *$ & 0.104 & $0.598 * *$ & 0.107 & $0.587 * *$ & 0.103 & $0.590 * *$ & 0.103 \\
\hline $5+$ & $0.415^{* *}$ & 0.124 & $0.442 * *$ & 0.133 & $0.422 * *$ & 0.124 & $0.406 * *$ & 0.120 \\
\hline \multicolumn{9}{|l|}{ Household characteristics } \\
\hline Nuclear household & 0.947 & 0.171 & 0.897 & 0.160 & 0.905 & 0.162 & 0.963 & 0.172 \\
\hline Live children & 1.057 & 0.063 & 1.042 & 0.062 & 1.033 & 0.061 & 1.053 & 0.062 \\
\hline $\begin{array}{l}\text { Total household income per } \\
\text { adult equivalent (logged) }\end{array}$ & 1.063 & 0.117 & 1.088 & 0.121 & 1.057 & 0.117 & 1.048 & 0.116 \\
\hline \multicolumn{9}{|l|}{$\begin{array}{l}\text { Father's educational attainment } \\
\text { (None omitted) }\end{array}$} \\
\hline $1-4$ years & 1.113 & 0.283 & 1.011 & 0.248 & 1.041 & 0.241 & 1.144 & 0.281 \\
\hline $5-7$ years & $2.543 * *$ & 0.615 & $2.431 * *$ & 0.579 & $2.495 * *$ & 0.598 & $2.619 * *$ & 0.640 \\
\hline $8+$ years & $3.363 * *$ & 0.817 & $3.247 * *$ & 0.806 & $3.434 * *$ & 0.853 & $3.531 * *$ & 0.867 \\
\hline Household owns land & 1.276 & 0.235 & $1.445^{*}$ & 0.270 & $1.462 *$ & 0.267 & 1.278 & 0.234 \\
\hline Index of nonelectrical & & & & & & & & \\
\hline poss & $1.572 * *$ & 0.130 & $1.472 * *$ & 0.127 & $1.503 * *$ & 0.128 & $1.596 * *$ & 0.130 \\
\hline Mother ever attended school & $3.476 * *$ & 1.193 & $3.294 * *$ & 1.085 & $3.431 * *$ & 1.106 & $3.566 * *$ & 1.178 \\
\hline \multicolumn{9}{|l|}{ Community schooling } \\
\hline Middle school in village & $1.563 *$ & 0.296 & 1.462 & 0.337 & 1.488 & 0.354 & $1.555^{*}$ & 0.326 \\
\hline \multicolumn{9}{|l|}{ Individual-level women's status } \\
\hline Purdah outside home & 1.291 & 0.268 & 1.452 & 0.297 & & & & \\
\hline Mobility & 1.008 & 0.052 & 0.972 & 0.049 & & & & \\
\hline Fear of husband & 1.049 & 0.192 & 1.151 & 0.213 & & & & \\
\hline $\begin{array}{l}\text { Domestic violence } \\
\quad \text { (regularly beaten) }\end{array}$ & 0.799 & 0.274 & 0.732 & 0.239 & & & & \\
\hline Access to financial resources & 1.047 & 0.137 & 1.127 & 0.144 & & & & \\
\hline $\begin{array}{l}\text { Decisionmaking in regard } \\
\text { to children }\end{array}$ & 1.087 & 0.074 & 1.076 & 0.075 & & & & \\
\hline Spouse is older $(5+$ years $)$ & & & & & 1.100 & 0.191 & 1.058 & 0.183 \\
\hline \multicolumn{9}{|l|}{ Community-level women's status } \\
\hline Mobility & & & $1.576^{*}$ & 0.281 & $1.390 *$ & 0.231 & & \\
\hline Work outside home & & & 0.630 & 0.291 & 0.506 & 0.226 & & \\
\hline Fear of husband & & & $0.087 *$ & 0.090 & $0.120 *$ & 0.117 & & \\
\hline Mean spousal age difference & & & & & & & 0.975 & 0.111 \\
\hline Log likelihood & -658.8 & & -645 & .15 & -649 & .49 & -661 . & 46 \\
\hline Degrees of freedom & 20 & & 23 & & 18 & & 16 & \\
\hline
\end{tabular}

Note: $\mathrm{N}=1,406$. Standard errors (S.E.) are adjusted for clustering at the household level using HuberWhite correction.

$*^{*} \mathrm{p}<0.01 ; * \mathrm{p}<0.05$ 
uneducated fathers. Mother's school attendance is also a strong determinant. Children of mothers who ever attended school are 3.3 times more likely to ever attend school themselves than children whose mothers never attended school. After controlling for the community-level women's status indicators, the availability of a secondary school in the community is no longer statistically significant (whereas it was statistically significant at the .05 level in the first model). In other words, community levels of mobility and lower levels of fear of husbands may compensate to some extent for the lack of proximate schools.

As with the infant mortality model, we reran our models with the spousal age difference variable replacing the individual-level women's status variables. The inclusion of the spousal age difference variable in lieu of the more specific measures along with the three community variables (model 3 ) fails to substantially alter the results, reaffirming support of our hypothesis and supporting spousal age difference as a proxy for women's status measures at the individual level. Because community-level women's status variables are more important indicators of children's school attendance, we show the results for an additional model including a community measure of spousal age difference, specifically the mean age difference of women in the community and their spouses (model 4). At the community level, the average spousal age difference has a minimal effect and fails to achieve statistical significance. Furthermore, unlike at the individual level, it does not appear to be a sound proxy for the three measures of women's status used in model 2.

It is possible that the apparent relationships between women's status and lower infant mortality and women's status and improved children's school attendance are driven by differentials specific to the sex of the child (such as found by Stash and Morgan 1999). In looking at the relationship between women's work activities and infant and child mortality in India, Kishor and Parasuraman (1998) find that the negative relationship is explained by the strong link between women's work and reduced survival of infant sons, whereas the survival of infant daughters is not significantly affected by mother's work. In other words, their findings indicate that the sex of the child is an important intermediate variable in the relationship. A similar situation may be occurring in rural Punjab. Unfortunately, our limited sample size and the relatively rare occurrence of infant mortality do not allow us to investigate this. We can do so for children's schooling, however. 
An extension of the same logic behind our hypothesis that community-level women's status will improve the ability of women to invest in their children through education is the idea that this investment should be particularly strong for girls. A community environment favorable for women will also be more favorable for girls. In a country where the schooling of girls is much less common than schooling of boys, we would expect less of a difference in girls' and boys' school attendance in areas with lower levels of patriarchy and repression of women. Thus, women's status at the community level may be a stronger determinant of school attendance for girls than for boys. This is especially true given that there is room for vast improvement in girls' schooling in rural Punjab, as evidenced in Table 3 and the substantially higher likelihood of ever attending school for boys in the multivariate model.

We ran the second schooling model separately for girls and boys and present the results in Table 6. The results indicate that the influence of women's status may operate differently for boys and girls. Specifically, the community-level indicators of women's status are significant for girls but not for boys. There are also differences in the individual-level measures of mother's status for boys and girls. Most notably, mother's education has a much greater effect on boys' schooling than it does on girls' schooling. Controlling for individual and community aspects of women's status, boys with mothers who ever attend school are 6.7 times more likely to ever attend school themselves than those with mothers who never attended school, whereas the effect of maternal education on girls is significantly lower (although it is still substantial) with an odds ratio of nearly 3.0. Also, boys with mothers who are regularly beaten by their husbands are only 0.4 times as likely to ever attend school as boys with mothers whose husbands do not regularly beat them. Together these results suggest that girls benefit more than boys from living in communities where women on the whole have more status. However, they also indicate that the status of mothers on an individual level may offer benefits to boys as opposed to girls.

The first two models in Table 6 also indicate that girls with mothers who practice purdah outside the home are 1.8 times more likely to attend school than those with mothers who do not practice purdah outside the home, whereas this variable has no significant effect on the school attendance of boys. Because this relationship is in the opposite direction from that expected, we revisited the descriptive statistics with par- 
Table 6 Logistic regression results (odds ratios) by sex for model of children ever attending school, rural Punjab

\begin{tabular}{|c|c|c|c|c|c|c|c|c|}
\hline \multirow[b]{3}{*}{ Variable } & \multirow{2}{*}{\multicolumn{2}{|c|}{ Boys }} & \multirow{2}{*}{\multicolumn{2}{|c|}{ Girls }} & \multicolumn{4}{|c|}{ Controlling for residence in Dab } \\
\hline & & & & & \multicolumn{2}{|c|}{ Boys } & \multicolumn{2}{|c|}{ Girls } \\
\hline & $\begin{array}{l}\text { Odds } \\
\text { ratio }\end{array}$ & S.E. & $\begin{array}{l}\text { Odds } \\
\text { ratio }\end{array}$ & S.E. & $\begin{array}{l}\text { Odds } \\
\text { ratio }\end{array}$ & S.E. & $\begin{array}{l}\text { Odds } \\
\text { ratio }\end{array}$ & S.E. \\
\hline \multicolumn{9}{|l|}{ Individual characteristics } \\
\hline Age & $1.120 *$ & 0.052 & 0.956 & 0.043 & $1.118^{*}$ & 0.052 & 0.964 & 0.043 \\
\hline \multicolumn{9}{|l|}{ Birth order ( 1 omitted $)$} \\
\hline $2-4$ & $0.564 *$ & 0.158 & $0.543 *$ & 0.133 & $0.568 *$ & 0.160 & $0.553^{*}$ & 0.135 \\
\hline $5+$ & 0.556 & 0.244 & $0.302 * *$ & 0.119 & 0.566 & 0.250 & $0.318 * *$ & 0.125 \\
\hline \multicolumn{9}{|l|}{ Household characteristics } \\
\hline Nuclear household & 1.008 & 0.252 & 0.823 & 0.192 & 1.001 & 0.251 & 0.865 & 0.202 \\
\hline Live children & 0.914 & 0.073 & $1.208 *$ & 0.093 & 0.914 & 0.073 & $1.219 * *$ & 0.092 \\
\hline $\begin{array}{l}\text { Total household income per } \\
\text { adult equivalent (logged) }\end{array}$ & 1.021 & 0.157 & 1.093 & 0.155 & 1.027 & 0.154 & 1.103 & 0.155 \\
\hline \multicolumn{9}{|l|}{$\begin{array}{l}\text { Father's educational attainment } \\
\text { (None omitted) }\end{array}$} \\
\hline $1-4$ years & 1.578 & 0.662 & 0.728 & 0.296 & 1.635 & 0.689 & 0.741 & 0.304 \\
\hline $5-7$ years & $2.838 * *$ & 1.085 & $2.399 * *$ & 0.673 & $2.805 * *$ & 1.069 & $2.119 * *$ & 0.603 \\
\hline $8+$ years & $3.707 * *$ & 1.239 & $3.164 * *$ & 0.941 & $3.495 * *$ & 1.180 & 2.746 & 0.842 \\
\hline Household owns land & 1.040 & 0.269 & $1.961 * *$ & 0.499 & 0.991 & 0.253 & $1.875^{*}$ & 0.492 \\
\hline Index of nonelec & & & & & & & & \\
\hline possessions & $1.463 * *$ & 0.170 & $1.487 * *$ & 0.154 & $1.479 * *$ & 0.175 & $1.525^{* *}$ & 0.162 \\
\hline Mother ever attended school & $6.725^{* *}$ & 4.886 & $2.978 * *$ & 1.206 & $6.811 * *$ & 4.954 & $3.169 * *$ & 1.212 \\
\hline \multicolumn{9}{|l|}{ Community schooling } \\
\hline Middle school in village & 1.597 & 0.550 & $1.781 *$ & 0.514 & 1.406 & 0.490 & 1.363 & 0.414 \\
\hline \multicolumn{9}{|l|}{ Individual-level women's status } \\
\hline Purdah outside home & 1.212 & 0.353 & $.774 *$ & 0.477 & 1.134 & 0.333 & 1.557 & 0.422 \\
\hline Mobility & 0.907 & 0.059 & 1.033 & 0.066 & 0.911 & 0.059 & 1.037 & 0.065 \\
\hline Fear of husband & 1.407 & 0.386 & 0.901 & 0.222 & 1.386 & 0.384 & 0.923 & 0.228 \\
\hline $\begin{array}{l}\text { Domestic violence } \\
\quad \text { (regularly beaten) }\end{array}$ & $430 *$ & 184 & & 3 & & 35 & & \\
\hline Access to financial resources & 1.186 & 0.223 & 1.092 & 0.169 & 1.202 & 0.227 & 1.134 & 0.180 \\
\hline $\begin{array}{l}\text { Decisionmaking in regard } \\
\text { to children }\end{array}$ & 1.100 & 0.097 & 1.093 & 0.100 & 1.090 & 0.096 & 1.086 & 0.102 \\
\hline \multicolumn{9}{|l|}{ Community-level women's status } \\
\hline Mobility & 1.357 & 0.355 & $2.030 * *$ & 0.489 & 1.556 & 0.467 & $3.144 * *$ & 0.967 \\
\hline Work outside home & 0.912 & 0.583 & 0.348 & 0.204 & 1.171 & 0.782 & 0.790 & 0.541 \\
\hline Fear of husband & 0.136 & 0.222 & $0.072 *$ & 0.092 & 0.141 & 0.222 & $0.058 *$ & 0.072 \\
\hline Lives in Dab & & & & & 2.271 & 1.780 & $4.955^{*}$ & 3.112 \\
\hline Log likelihood & -284 & & -343 & & -283 & & -338 & \\
\hline Degrees of freedom & 22 & & 22 & & 23 & & 23 & \\
\hline $\mathrm{N}$ & 712 & & 69 & & 712 & & 69 & \\
\hline
\end{tabular}

Note: Standard errors (S.E.) are adjusted for clustering at the household level using Huber-White correction. $* * \mathrm{p}<0.01 ; * \mathrm{p}<0.05$ 
ticular attention to the distributions of these variables within each village. One of the villages, Dab, has high levels of girls' schooling (as shown in Table 3) and unusually high levels of women who practice purdah outside the home, although these variables are not necessarily associated. In fact, Dab was the only village in the sample in which more women reported practicing purdah outside the home than not: 88 percent of girls in the schooling sample in Dab have mothers who practice purdah outside the home, whereas for the other nine villages the figure is between 6 and 41 percent. In the second two models presented in Table 6, we include a control variable for those residing in Dab to control for the unique situation in this village. The results show that after controlling for residence in Dab, the mother's practice of purdah is not statistically significant for girls. The addition of this variable has little effect on the other variables in the model in terms of either the value of the coefficient or statistical significance. The communitylevel women's status variables remain strong and significant for girls, and mother's education remains particularly strong for boys. ${ }^{10}$ However, these results do indicate that the mother's practice of purdah may be a weak measure of women's status because the determinants of its practice are so varied and complex (Amin 1997). Not only are the results associated with the measure difficult to interpret in general (i.e., what purdah indicates about women's status), but the practice of purdah in Dab likely means something very different than it does in the other villages.

\section{CONCLUSIONS AND POLICY RECOMMENDATIONS}

The findings presented in the previous section support the conclusion that empowered women, or those with higher status, are better able to make positive investments in their children through increasing their chances of survival during infancy and increasing their likelihood of ever attending school. Overall, the data support our hypotheses that improvements in women's status at the individual level, particularly in terms of improvement of women's position in the household, will enhance child survival and the school attendance of their sons, whereas improvements in women's status at the community level are more important for improving the schooling chances of children, especially girls, in rural Punjab. Specifically, lower levels of women's status at the individual level, particularly in terms of physical abuse by husbands, limited access to 
financial resources, and purdah restrictions, increase the likelihood of infant mortality. On the other hand, higher mean levels of women's mobility and a lower percentage of women who fear to disagree with their husbands in a community are associated with a higher likelihood that children, especially girls, will ever attend school in rural Punjab.

This study thus contributes to the literature on the relationship between women's status and demographic outcomes in three main ways. First, it informs us of potential factors that might improve the situation of children in regard to their health and education in an area where change is greatly needed. Not only is enhancing women's status important in its own right, it has measurable benefits for the health and education of children. Further, the results point to specific aspects of women's status on which efforts should be focused. Individual-level indicators of status, such as fear of husbands, fear of violence by husbands, and women's access to financial resources, appear to be more important than those related to decisionmaking on the part of women. These findings are certainly important in terms of emphasizing routes to women's empowerment, such as addressing domestic violence and the isolation of women. The results place issues of increasing participation in decisionmaking and mobility of individual women in perspective.

Second, this study provides an empirical test of the theoretical framework of women's status on demographic outcomes, advancing the importance of capturing various dimensions of women's status on multiple levels to fully understand the relationship between women's status and specific demographic outcomes. Our results clearly point to the multidimensionality of women's status and demonstrate that different indicators of women's status are associated with different demographic outcomes for women as well as for their sons and daughters.

It is in the combination of the results from our models that we find the most informative insight into the multidimensional nature of women's status and its influence on child wellbeing and demographic outcomes. The status of women is important for both infant survival and child schooling, but in very different ways. Infant mortality, more in the domain of the woman and her household, is influenced by the status of mothers in the household as reflected by the significance of purdah restrictions, access to financial resources, and domestic violence (and age differences between her and her spouse at a general level). On the other hand, children's schooling - a decision with 
more long-term and public consequences in terms of employment and marriage opportunities-may be less subject to the influence of a single agent, including the mother. A rise in women's status - or in the value of women and girls in the larger communitywill shape decisions that individual families make about such activities as schooling for their children.

The findings thus indicate the importance of context and community characteristics when creating a propitious environment, particularly for investments in infant survival and schooling for girls. Gender norms regarding mobility and freedom from repression by men are important because they not only determine outcomes, such as children's schooling chances, but they also affect the impact of other characteristics of the community such as socioeconomic distinctions among the populace. In other words, community measures of gender or women's status have an interactive relationship with individual characteristics of the women who live there. These are hard to translate and interpret because they vary by context. The strong implication for policy is that while improvements in women's status will definitely reap rewards, contextual effects also play an important role in determining what impact they have on outcomes, such as investments in children's schooling and infant mortality.

Ultimately this study reinforces the point that while raising the status of women is a well-intended and positive end in itself, the benefits extend to investments in the next generation. In turn, improvements in children's schooling and in their chances of survival closely influence the quality of lives of women and families in a much broader sense. 


\section{Appendix Definition of variables used in analysis}

\section{Variable}

Individual-level women's status

Purdah outside home

Mobility (index mean)

Fear of husband

Domestic violence

Access to financial resources

Decisionmaking in regard to children

Spouse is older $(5+$ years $)$

\section{Community-level women's status \\ Mobility}

Work outside home

Fear of husband

Mean spousal age difference

\section{Control}

Sex of child

Age of child

Birth order

Previous infant death in family

Short preceding birth interval
Definition

Woman reports practicing purdah outside the home. Index indicating whether woman can go alone $(+1)$ and without permission $(+1)$ to market, health center, and friend's/relative's house (range, 0-6).

Woman reports frequently being afraid to disagree with her husband (Yes=1).

Categorical variable of domestic violence; woman reports being beaten by her husband never, sometimes, or regularly.

Index of two variables indicating woman's access to financial resources in the household: woman has household money in hand to use; and woman owns land, jewelry, or other valuables that she can use as she pleases (range, 0-2).

Index indicating the extent of woman's participation in household decisions regarding children, including whether to punish children, what to do if a child is sick, how much schooling children should receive, and what kind of schooling children should receive (range, 0-4). Spouse is five or more years older than woman (Yes=1).

Mean mobility index for each community (excluding the respondent).

Percentage of women in community who work outside the home (excluding the respondent).

Percentage of women in community who say they are frequently afraid to disagree with their husbands (excluding the respondent).

Average age difference between women in community and their husbands.

Boy $=1$

Child's age in years.

Categorical variable indicating birth order of child; possible categories include: $1,2-4$, and $5+(1$ is the omitted category)

Dummy variable; previous live birth to mother died before the age of 12 months (Yes=1)

Preceding birth interval less than 24 months (Yes=1; first-order children coded as 0 ).

continued 


\section{Appendix (continued)}

Variable

Age of mother at birth of child (years)

Husband is blood relative

Total household income

per adult equivalent

Father's educational attainment

Mother ever attended school

Household owns land

Index of nonelectrical possessions

Nuclear household

Live children

Distance to health facility

Middle school in village

\section{Definition}

Categorical variable indicating mother's age at birth of her child; possible categories include: $<20,20-34,35+$ (20-34 is the omitted category).

Dummy variable; mother reports that her husband is a cousin, uncle, or other relative (Yes=1).

Total household income divided by the number of adultequivalent household residents using the following scale: 0.2 for age $0-6 ; 0.3$ for age $7-12 ; 0.5$ for age 13-17; and 1 for age $18+$.

Categorical variable of father's highest level of completed education; categories include: None, 1-4 years, 5-7 years, $8+$ years (None is the omitted category).

Dummy variable; mother reports ever attending school (Yes=1).

Household has land holdings of any size for agricultural or nonagricultural purposes (Yes=1). Number of nonelectrical appliances that the household has in its possession.

Household is nuclear (includes parents and immediate children only; Yes=1).

Total number of live children in the family.

Community-level variable; reported distance to the nearest health facility from the village (in kilometers). Community-level variable; village has any middle school within its boundaries (Yes=1). 


\section{Notes}

1. The relationship between women's education and status is tentatively supported by Basu (1992), however, in her study of women's status and demographic behavior in India.

2. A preliminary model also included a variable indicating whether the mother-inlaw of the woman was present in the household, because the position of women in relation to other women in the household (particularly the mother-in-law) is believed to be an important aspect of a woman's status. However, this variable was highly correlated with "nuclear household" and failed to demonstrate a relationship with either infant mortality or children's schooling that could be distinguished from the difference between nuclear and extended households.

3. We explored the possibility of combining the fear of disagreeing with husband and the domestic violence measures into a single measure; however, this categorical variable (including four possible combinations of fear and violence) proved difficult to interpret. Specifically, there were a number of women who were not afraid to disagree with their husbands despite being beaten as well as a number who were afraid but not beaten. Because of this difficulty, as well as the likelihood that these measures are related to different aspects of women's status, we chose to include them independently.

4. The child decisionmaking index and the mobility index demonstrated strong results with eigenvalues over 1.0 and factor loadings above 0.4 (with most variables having factor loadings above 0.7 ). The husband communication index variables had high factor loadings (above 0.6), although the eigenvalue was only 0.92 . Finally, the access to money index variables had factor loadings of 0.45 and 0.50 , but a low eigenvalue. All other variables included in the factor analysis failed to load on one of these first four factors and demonstrated uniqueness values above 0.7 . 
5. Other studies examining women's status in rural Punjab using these data also provide descriptions of women's status overall as well as by community (Kazi and Sathar 1996; Mason 1998; Sathar and Kazi 1997). These findings further support variability in the indicators by village.

6. Research has also shown a higher risk of mortality for children with a short subsequent birth interval due to sibling competition.

7. Higher infant mortality among consanguineous couples is believed to be partially explained by deleterious genetic effects of inbreeding, in particular a greater frequency of recessive phenotypes (Weiss 1990).

8. Albeit the schools are of varying quality and accessibility.

9. We ran the model by omitting practice of purdah outside the home to see whether this variable had an effect on the mobility index, but there was no difference in the variable or in the model with this variable excluded.

10. We also reran the infant mortality model with a control variable for Dab. The addition of the variable for Dab had only minor effects on the coefficients and failed to alter the statistical significance of any of the variables. 


\section{References}

Agha, Sohail. 2000. "The determinants of infant mortality in Pakistan," Social Science and Medicine 51: 199-208.

Amin, Sajeda. 1997. "The poverty-purdah trap in rural Bangladesh: Implications for women's roles in the family," Development and Change 28: 213-233.

Balk, Deborah. 1994. "Individual and community aspects of women's status and fertility in rural Bangladesh," Population Studies 48(1): 21-45.

—_ 1997. "Defying gender norms in rural Bangladesh: A social demographic analysis," Population Studies 51: 153-172.

Basu, Alaka Malwade. 1992. Culture, the Status of Women, and Demographic Behaviour: Illustrated with the Case of India. Oxford, UK: Clarendon Press.

—_ 1994. "Maternal education, fertility and child mortality: Disentangling verbal relationships," Health Transition Review 4(2): 207-215.

Basu, Alaka Malwade and Kaushik Basu. 1991. "Women's economic roles and child survival: The case of India," Health Transition Review 1(1): 83-103.

Bicego, George T. and J. Ties Boerma. 1991. "Maternal education and child survival: A comparative analysis of DHS data," in Proceedings of the Demographic and Health Surveys World Conference, August 5-7, 1991, vol. 1. Calverton, MD: Macro International, pp. 177-204.

Bittles, A. H., J. C. Grant, and S. A. Shami. 1993. "An evaluation of consanguinity as a determinant of reproductive behavior and mortality in Pakistan," International Journal of Epidemiology 22: 463-467.

Boerma, J. Ties and George T. Bicego. 1992. "Preceding birth intervals and child survival: Searching for pathways of influence," Studies in Family Planning 23(4): 243-256.

Cain, Mead T. 1993. "Patriarchal structure and demographic change," in Nora Federici, Karen Oppenheim Mason, and Sølvi Sogner (eds.), Women's Position and Demographic Change. Oxford, UK: Clarendon Press, pp. 43-60.

Caldwell, John C. 1979. "Education as a factor in mortality decline: An examination of Nigerian data," Population Studies 33(3): 395-413. 
1994. "How is greater maternal education translated into lower child mortality?" Health Transition Review 4: 224-229.

Caldwell, John and Pat Caldwell. 1993. "Women's position and child mortality and child morbidity in less developed countries," in Nora Federici, Karen Oppenheim Mason, and Sølvi Sogner (eds.), Women's Position and Demographic Change. Oxford, UK: Clarendon Press, pp. 122-139.

Cleland, John. 1990. "Maternal education and child survival: Further evidence and explanations," in J. C. Caldwell et al. (eds.), What We Know About Health Transition: The Cultural, Social and Behavioural Determinants of Health, vol. 1. Canberra: Australian National University, pp. 400-419.

Curtis, Siân, Ian Diamond, and John W. McDonald. 1993. "Birth interval and family effects on postneonatal mortality in Brazil," Demography 30: 33-43.

Das Gupta, Monica. 1997. "Socio-economic status and clustering of child deaths in rural Punjab," Population Studies 51: 191-202.

Desai, Sonalde and Soumya Alva. 1998. "Maternal education and child health: Is there a strong causal relationship?" Demography 35(1): 71-81.

Durrant, Valerie L. 1998. “Limited options or missed opportunities: Children's work and schooling in Pakistan," unpublished doctoral dissertation. University of Maryland, College Park.

Dyson, Tim and Mick Moore. 1983. "On kinship structure, female autonomy, and demographic behavior in India," Population and Development Review 9(1): 35-60.

Federici, Nora, Karen Oppenheim Mason, and Sølvi Sogner. 1993. "Introduction," in Nora Federici, Karen Oppenheim Mason, and Sølvi Sogner (eds.), Women's Position and Demographic Change. Oxford, UK: Clarendon Press, pp. 1-15.

Gazdar, Haris. 1999. "Universal basic education in Pakistan: A commentary on strategy and results of a survey," Sustainable Development Policy Institute Working Paper no. 39. Islamabad, Pakistan: Sustainable Development Policy Institute.

Glewwe, Paul. 1999. "Why does mother's schooling raise child health in developing countries? Evidence from Morocco," Journal of Human Resources 34: 124-159.

Government of Pakistan. 1997. Pakistan Integrated Household Survey, Round 2: 1996-97. Islamabad, Pakistan: Federal Bureau of Statistics. 
Guo, Guang. 1993. "Use of sibling data to estimate family mortality effects in Guatemala," Demography 30: 15-32.

Hill, M. Anne and Elizabeth M. King. 1993. "Women's education in developing countries: An overview," in Elizabeth M. King and M. Anne Hill (eds.), Women's Education in Developing Countries: Barriers, Benefits, and Policies. Baltimore, MD: Johns Hopkins University Press, pp. 1-50.

Hobcraft, John N. 1993. "Women's education, child welfare and child survival: A review of the evidence," Health Transition Review 3: 159-175.

Hobcraft, John N., John W. McDonald, and Shea O. Rutstein. 1983. "Child-spacing effects on infant and early child mortality," Population Index 49: 585-618.

—_ 1984. "Socio-economic factors in infant and child mortality: A cross-national comparison," Population Studies 38: 193-223.

—_ 1985. "Demographic determinants of infant and early childhood mortality: A comparative analysis," Population Studies 39: 363-385.

Hossain, Mian B., James F. Philips, Brian Pence, and Ian D. Diamond. 2000. “The effect of constrained women's status on infant and child mortality in four rural areas of Bangladesh," paper presented at the Annual Meeting of the Population Association of America, Los Angeles, CA, 23-25 March.

Huber, P. J. 1967. "The behavior of maximum likelihood estimates under non-standard conditions," Proceedings of the Fifth Berkeley Symposium on Mathematical Statistics and Probability 1: 221-233.

Irfan, Mohammed. 1989. "Poverty, class structure and household demographic behaviours in rural Pakistan," in Gerry Rodgers (ed.), Population Growth and Poverty in Rural South Asia. New Delhi, India: Sage, pp. 76-120.

Jeffery, Roger and Alaka Malwade Basu (eds.). 1996. Girls' Schooling, Women's Autonomy and Fertility Change in South Asia. New Delhi, India: Sage.

Jejeebhoy, Shireen J. 1995. Women's Education, Autonomy, and Reproductive Behaviour: Experience from Developing Countries. Oxford, UK: Clarendon Press.

__ 1996. "Women's autonomy and reproductive behaviour in India: Linkages and influence of sociocultural context," in Comparative Perspectives on Fertility Transition in South Asia, vol. 1. Liège, Belgium: IUSSP, pp. 20-27. 
_ 1998. "Associations between wife-beating and fetal and infant death: Impressions from a survey in rural India," Studies in Family Planning 29(3): 300-308.

Kazi, Shahnaz and Zeba A. Sathar. 1996. "Explaining fertility in rural Punjab: The role of gender and development," paper presented at the IUSSP conference on Comparative Perspectives on Fertility Transition in South Asia, Rawalpindi, Pakistan, 17-19 December.

Khan, Sharukh R. 1993. "South Asia," in Elizabeth M. King and M. Anne Hill (eds.), Women's Education in Developing Countries: Barriers, Benefits, and Policies. Baltimore, MD: Johns Hopkins University Press, pp. 211-246.

Kishor, Sunita. 1993. "May God give sons to all': Gender and child mortality in India," American Sociological Review 58: 247-265.

_ 1995. "Autonomy and Egyptian women: Findings from the 1988 Egypt Demographic and Health Survey," DHS Occasional Papers no. 2. Calverton, MD: Macro International.

Kishor, Sunita and Sulabha Parasuraman. 1998. "Mother's employment and infant and child mortality in India," National Family Health Survey Subject Reports no. 8. Mumbai, India, and Calverton, MD: International Institute for Population Sciences and Macro International.

Koenig, Michael A., James F. Phillips, Oona M. Campbell, and Stan D’Souza. 1990. "Birth intervals and childhood mortality in rural Bangladesh," Demography 27: 251-265.

Leslie, Joanne and Mayra Buvinić. 1991. "Introduction," in Joanne Leslie and Michael Paolisso (eds.), Women, Work, and Child Welfare in the Third World. Boulder, CO: Westview, pp. 1-17.

Mahmood, Moazam, Tariq Javaid, and Ajmal Baig. 1994. "Why children do not go to school in rural Pakistan: Some estimates and a theoretical framework," Pakistan Development Review 33(4, part 2): 1231-1245.

Malhotra, Anju, Reeve Vanneman, and Sunita Kishor. 1995. "Fertility, dimensions of patriarchy, and development in India," Population and Development Review 21(2): 281-305.

Mason, Karen Oppenheim. 1984. "The status of women, fertility, and mortality: A review of interrelationships," University of Michigan Population Studies Center Research Report no. 84-58. Ann Arbor: University of Michigan. 
1987. "The impact of women's social position on fertility in developing countries," Sociological Forum 1(2): 284-300.

_ 1993. "The impact of women's position on demographic change during the course of development," in Nora Federici, Karen Oppenheim Mason, and Sølvi Sogner (eds.), Women's Position and Demographic Change. Oxford, UK: Clarendon Press, pp. 19-42.

. 1998. "Wives' economic decision-making power in the family: Five Asian countries," in Karen Oppenheim Mason, Noriko O. Tsuya, and Minja Kim Choe (eds.), The Changing Family in Comparative Perspective: Asia and the United States. Honolulu, HI: East-West Center, pp. 105-133.

Morgan, S. Philip and Bhanu B. Niraula. 1995. "Gender inequality and fertility in two Nepali villages," Population and Development Review 21(3): 541-561.

Pinnelli, Antonella. 1993. "The condition of women and the health and mortality of infants and children," in Nora Federici, Karen Oppenheim Mason, and Sølvi Sogner (eds.), Women's Position and Demographic Change. Oxford, UK: Clarendon Press, pp. 162-189.

Sastry, Narayan. 1997. "Family-level clustering of childhood mortality risk in northeast Brazil,” Population Studies 51: 245-261.

Sathar, Zeba A. 1987. "Seeking explanations for high levels of infant mortality in Pakistan," Pakistan Development Review 26: 55-70.

— 1993. Women's Status and Fertility in Pakistan: Recent Evidence. New York: United Nations.

—_ 1995. "The relationship between poverty and infant mortality in Pakistan," paper presented at the Annual Meeting of the Population Association of America, San Francisco, CA, 6-8 April.

Sathar, Zeba A. and John B. Casterline. 1998. "The onset of fertility transition in Pakistan," Population and Development Review 24(4): 773-796.

Sathar, Zeba, Nigel Crook, Christine Callum, and Shahnaz Kazi. 1988. "Women's status and fertility change in Pakistan," Population and Development Review 14(3): 415-432. 
Sathar, Zeba A. and Shahnaz Kazi. 1996. "Women's autonomy and the onset of fertility change in rural Pakistan: The significance of gender inequality across communities," paper presented at the Annual Meeting of the Population Association of America, New Orleans, LA, 9-11 May.

- 1997. Women's Autonomy, Livelihood and Fertility: A Study of Rural Punjab. Islamabad, Pakistan: Pakistan Institute of Development Economics.

Sathar, Zeba and Cynthia B. Lloyd. 1994. "Who gets primary schooling in Pakistan: Inequalities among and within families," Pakistan Development Review 33(2): 103-134.

Sathar, Zeba, Cynthia B. Lloyd, and Minhaj ul Haque. 2000. Investments in Children's Education and Family-building Behavior in Pakistan: Findings from Rural NWFP and Punjab. Islamabad, Pakistan: Population Council.

Schuler, Sidney Ruth and Syed M. Hashemi. 1994. "Credit programs, women's empowerment, and contraceptive use in rural Bangladesh," Studies in Family Planning 25(2): 65-76.

Shah, Gulzar H., Michael B. Toney, and Brian L. Pitcher. 1998. "Consanguinity and child mortality: The risk faced by families," Population Research and Policy Review 17: 275-283.

Smith, Herbert L. 1989. "Integrating theory and research on the institutional determinants of fertility," Demography 26(2): 171-184.

Smith, Herbert L. et al. 1995. "The impact of women's status on the unmet need for contraception in five Asian countries (starting with Pakistan and the Philippines)," unpublished mimeo.

Stash, Sharon and S. Philip Morgan. 1999. "Women's mobility and basic education: Community and family level correlates of primary schooling in Pakistan, India, and Nepal," paper presented at the Annual Meeting of the Population Association of America, New York, NY, 25-27 March.

Strauss, J. and Duncan Thomas. 1995. "Human resources: Empirical modeling of household and family decisions," in J. Behrman and T. N. Srinivasan (eds.), Handbook of Development Economics, vol. IIIA. Amsterdam, The Netherlands: Elsevier, pp. 1920-1948. 
Stromquist, Nelly P. 1989. "Determinants of educational participation and achievement of women in the Third World: A review of the evidence and a theoretical critique," Review of Educational Research 59(2): 143-183.

Uchudi, Joseph Masudi. 2000. "Gender context and fertility differences in sub-Saharan Africa," paper presented at the Annual Meeting of the Population Association of America, Los Angeles, CA, 23-25 March.

United Nations, Department of International Economic and Social Affairs. 1985. Socioeconomic Differentials in Child Mortality in Developing Countries. New York: United Nations.

United Nations, Department for Economic and Social Information and Policy Analysis. 1993. Women's Status and Fertility in Pakistan: Recent Evidence. New York: United Nations.

Visaria, Leela. 1996. "Regional variations in female autonomy and fertility and contraception in India," in Roger Jeffery and Alaka Malwade Basu (eds.), Girls'Schooling, Women's Autonomy and Fertility Change in South Asia. New Delhi, India: Sage, pp. 235-268.

Ware, Helen. 1984. "Effects of maternal education, women's roles, and child care on child mortality," in W. Henry Mosley and Lincoln C. Chen (eds.), Child Survival: Strategies for Research, supplement to Population and Development Review, vol. 10. New York: Population Council, pp. 191-214.

Weiss, Kenneth M. 1990. "The biodemography of variations in human frailty," Demography 27: 185-206.

White, H. 1980. "A heteroskedasticity-consistent covariance matrix estimator and a direct test for heteroskedasticity," Econometrica 48: 817-830.

World Bank. 1995. Pakistan Poverty Assessment. Washington, DC: World Bank.

—_ 1998. World Development Indicators 1998. Washington, DC: World Bank. 


\section{POLICY RESEARCH DIVISION WORKING PAPERS}

Recent Back Issues

1998

*106 Sajeda Amin and Gilda Sedgh, "Incentive schemes for school attendance in rural Bangladesh."

107 Martin Brockerhoff and Paul Hewett, "Ethnicity and child mortality in sub-Saharan Africa."

108 Ann E. Biddlecom and Bolaji M. Fapohunda, "Covert contraceptive use: Prevalence, motivations, and consequences."

109 John Bongaarts and Griffith Feeney, "On the quantum and tempo of fertility."

110 Barbara S. Mensch, Daniel Bagah, Wesley H. Clark, and Fred Binka, "The changing social environment for adolescents in the Kassena-Nankana District of northern Ghana: Implications for reproductive behavior."

111 Martin Brockerhoff and Ann Biddlecom, "Migration, sexual behavior, and HIV diffusion in Kenya."

112 Zeba A. Sathar and John B. Casterline, "The onset of fertility transition in Pakistan."

113 Geoffrey McNicoll, "Government and fertility in transitional and posttransitional societies."
*114 John Bongaarts, "Fertility and reproductive preferences in post-transitional societies."

115 Fiona Steele, Sajeda Amin, and Ruchira T. Naved, "The impact of an integrated micro-credit program on women's empowerment and fertility behavior in rural Bangladesh."

*116 Cynthia B. Lloyd, Barbara S. Mensch, and Wesley H. Clark, "The effects of primary-school quality on the educational participation and attainment of Kenyan girls and boys."

*117 Sajeda Amin and Cynthia B. Lloyd, "Women's lives and rapid fertility decline: Some lessons from Bangladesh and Egypt."

118 James F. Phillips and Mian Bazle Hossain, "The impact of family planning household service delivery on women's status in Bangladesh."

*119 Mark R. Montgomery and John B. Casterline, "Social networks and the diffusion of fertility control."

* No longer available 
*120 John Bongaarts, "The fertility impact of changes in the timing of childbearing in the developing world."

*121 James F. Phillips, Wendy L. Greene, and Elizabeth F. Jackson, "Lessons from community-based distribution of family planning in Africa."

122 Mark R. Montgomery, "Mortality decline and the demographic response: Toward a new agenda."

*123 Mark R. Montgomery, Mary ArendsKuenning, and Cem Mete, "The quantity-quality transition in Asia."

124 Barbara S. Mensch, Wesley H. Clark, Cynthia B. Lloyd, and Annabel S. Erulkar, "Premarital sex and school dropout in Kenya: Can schools make a difference?"

125 John Bongaarts and Rodolfo A. Bulatao, "Completing the demographic transition."

126 Geoffrey McNicoll, "Population weights in the international order."
127 Cynthia B. Lloyd, Carol E. Kaufman, and Paul Hewett, "The spread of primary schooling in sub-Saharan Africa: Implications for fertility change."

128 John B. Casterline, "The onset and pace of fertility transition: National patterns in the second half of the twentieth century."

129 Mark R. Montgomery, Michele Gragnolati, Kathleen Burke, and Edmundo Paredes, "Measuring living standards with proxy variables."

130 Bamikale Feyisetan and John B. Casterline, "Fertility preferences and contraceptive change in developing countries."

131 Martin Brockerhoff, "Urban growth in developing countries: A review of projections and predictions."

132 Omaima El-Gibaly, Barbara Ibrahim, Barbara S. Mensch, and Wesley H. Clark, "The decline of female circumcision in Egypt: Evidence and interpretation."

* No longer available 
133 Mary Arends-Kuenning and Sajeda Amin, "The effects of schooling incentive programs on household resource allocation in Bangladesh."

134 John Bongaarts and Charles F. Westoff, "The potential role of contraception in reducing abortion."

135 John B. Casterline and Steven W. Sinding, "Unmet need for family planning in developing countries and implications for population policy."
136 Carol E. Kaufman, Thea de Wet, and Jonathan Stadler, "Adolescent pregnancy and parenthood in South Africa."

137 Valerie L. Durrant and Zeba A. Sathar, "Greater investments in children through women's empowerment: A key to demographic change in Pakistan?" 